NBER WORKING PAPER SERIES

\title{
WHO PAYS FOR AND WHO BENEFITS FROM MINIMUM WAGE INCREASES? EVIDENCE FROM ISRAELI TAX DATA ON BUSINESS OWNERS AND WORKERS
}

\author{
Lev Drucker \\ Katya Mazirov \\ David Neumark \\ Working Paper 26571 \\ http://www.nber.org/papers/w26571 \\ NATIONAL BUREAU OF ECONOMIC RESEARCH \\ 1050 Massachusetts Avenue \\ Cambridge, MA 02138 \\ December 2019, Revised March 2021
}

The views expressed are those of the authors alone, and do not represent the views of the Israel Ministry of Finance or the National Bureau of Economic Research. We are very grateful to Tatiana Slobodnitsky for help with tax data issues, and to anonymous reviewers and seminar participants at Beijing Normal University, DIW-Berlin, and Renmin University for helpful comments. We thank Kosta Kosenko for sharing his data on publicly-traded companies in Israel.

NBER working papers are circulated for discussion and comment purposes. They have not been peer-reviewed or been subject to the review by the NBER Board of Directors that accompanies official NBER publications.

(C) 2019 by Lev Drucker, Katya Mazirov, and David Neumark. All rights reserved. Short sections of text, not to exceed two paragraphs, may be quoted without explicit permission provided that full credit, including $\odot$ notice, is given to the source. 
Who Pays for and Who Benefits from Minimum Wage Increases? Evidence from Israeli Tax Data on Business Owners and Workers

Lev Drucker, Katya Mazirov, and David Neumark

NBER Working Paper No. 26571

December 2019, Revised March 2021

JEL No. H22,H23,J23,J38

\begin{abstract}
A key goal of a higher minimum wage is income redistribution towards low-income families. Existing research on the minimum wage focuses on the impact on affected workers, but is silent on the incomes of the owners of businesses who pay for a higher minimum wage. Higher minimum wages will do more to redistribute income if the owners of businesses who pay the minimum wage are nearer the top of the income distribution, and vice versa. We study evidence on the incidence of the minimum wage on the incomes of business owners using a unique administrative dataset on the universe of tax records for Israel, in the period surrounding a large minimum wage increase. We find that the minimum wage hike reduced profits of companies, with minimum-wage intensive companies bearing the bulk of the cost and adjusting their workforces more aggressively. Notably, profits declined more for lower-income business owners. Moreover, owners of businesses with higher shares of minimum-wage workers ranked at the bottom of the income distribution of business owners. In addition, spouses of business owners earn less than the owners while minimum wage workers have higher earning spouses, further reducing the redistributive effect of the minimum wage.
\end{abstract}

Lev Drucker

Israel Ministry of Finance

Eliezer Kaplan 1

Jerusalem

Israel

lev.drucker@gmail.com

Katya Mazirov

Israel Ministry of Finance

Eliezer Kaplan 1

Jerusalem

Israel

katyam@mof.gov.il
David Neumark

Department of Economics

University of California, Irvine

3151 Social Science Plaza

Irvine, CA 92697

and NBER

dneumark@uci.edu 


\section{Introduction}

At its core, the minimum wage is a redistributive policy, meant to increase incomes of low-income families. In the U.S. context, Senator Edward Kennedy, a perennial sponsor of minimum wage increases, argued that "The minimum wage was one of the first - and is still one of the best - anti-poverty programs we have” (Clymer, 1999, p. 449).

Existing research on the minimum wage focuses on the impact on affected workers. Not surprisingly, minimum wages raise wages of affected workers. A good deal of evidence concludes that higher minimum wages reduce employment of the least-skilled (Neumark and Shirley, 2021), but this conclusion is contested, with some recent evidence to the contrary (e.g., Cengiz et al., 2019); and recent evidence indicates that far more workers may experience wage gains than job losses, in part because estimated job losses are small (Harasztosi and Lindner, 2019). In terms of redistribution, researchers have focused on whether minimum wages reduce poverty or "near-poverty" (being below one-half of the poverty line). Most research tends to find no statistically significant evidence of poverty reductions (e.g., Sabia and Nielsen, 2015), although the point estimates tend to point in this direction (see, e.g., Neumark, 2016; Dube, 2018), and one recent study finds evidence of substantial poverty reductions (Dube, 2019). Another potentially important dimension of the relationship between the distributional effects of minimum wages and the impact of minimum wages is not who benefits from the minimum wage, but who pays for it. However, the research literature is silent on the incomes of the owners of businesses who pay for a higher minimum wage. Higher minimum wages will do more to redistribute income if the owners of businesses who pay the higher minimum wage are nearer the top of the income distribution. Conversely, if minimum wage employers have relatively low incomes, the redistributional effects are weakened, and - on this dimension at least - minimum wages would be less effective at redistributing income from highincome individuals or families to low-income individuals or families. ${ }^{1}$

Casual evidence on the distributional effects of the incidence of the minimum wage on businesses

\footnotetext{
${ }^{1}$ In this regard, the minimum wage could be quite different from redistributional policies financed by taxes - such as the U.S. Earned Income Tax Credit - which, by construction, redistribute income from those who pay the most taxes. How progressive this financing of the redistribution is depends, of course, on the progressivity of the tax system.
} 
appears to point in a number of possible directions. There are likely many relatively small, lower-income business owners (“mom and pop” shops) who use low-skill workers and hence will have to pay for higher minimum wages. But there are also some large corporations (e.g., Wal-Mart) that also pay relatively low wages. On the other hand, there are clearly many higher-income business owners, investors, and salaried workers who will not pay directly for a higher minimum wage, and it seems likely that this is true of many of those who have had the highest income growth in recent years. ${ }^{2}$

Researchers have lacked the data to study the distributional effects of the incidence of the minimum wage on business owners. In this paper, we study this question using matched administrative data from the universe of tax records for workers, firms, and firm owners in Israel. We study a large minimum wage increase that was an exogenous event driven by political events, to provide evidence on the incidence of the costs of higher minimum wages with respect to the family incomes of business owners, and the family income distribution more generally. We believe this is the first evidence on the incomes of business owners who pay for higher minimum wages and their position in the income distribution.

Distinguishing companies by the fraction of full-year workers earning at or below the new minimum wage prior to its increase (which we denote $F M W$ ), we find that the minimum wage hike reduced profits of companies, with minimum-wage intensive companies bearing the bulk of the cost and adjusting their workforces more aggressively. Notably, profits declined more for lower-income business owners. Moreover, owners of businesses with higher shares of minimum-wage workers ranked at the bottom of the income distribution of business owners. In addition, spouses of business owners earn less than the owners while minimum wage workers (i.e., those working at companies with high FMW) have higher earning spouses, further reducing the redistributive effect of the minimum wage.

\section{Minimum Wages in Israel}

The first minimum wage in Israel resulted from a 1972 collective labor agreement setting the minimum wage as a percentage of the average wage in the economy. The minimum wage is set in hourly and monthly terms, based on full-time work. Since 1987, the minimum wage level is set by legislation,

\footnotetext{
${ }^{2}$ In the United States, the surge in top incomes has been mostly associated with capital income (Piketty et al., 2018).
} 
initially constrained to no less than $39 \%$ of the average wage (based on full-time and part-time jobs in the entire economy), which rose to 45\% in April 1988 and 47.5\% in April 1997. In setting the nominal minimum wage, this mandated percentage was used as guidance rather than for consistent and explicit indexation.

The minimum wage "event” we study is the set of increases that occurred from 2006 through 2008. As shown in Figure 1, there were no increases in the nominal minimum wage in the few years preceding 2006. There were four increments in the $2006-2008$ period, leading to a sizable $15.4 \%$ increase in the nominal minimum wage. ${ }^{3}$ There were then no changes to the nominal minimum wage from 2008 until 2011. In addition to the minimum wage history in this period providing stable pre- and post-periods, the 2006-2008 increases were large and plausibly exogenous (as discussed below). ${ }^{4}$ The 2006-2008 minimum wage increases led to a large increase in the minimum wage relative to average wages in this period. In the three periods 2003-2005 (pre-period), 2006-2008 (treatment period), and 2009-2010 (post-period), the real changes in the minimum wage were $-1.3 \%,+8.3 \%$, and $-6.4 \%$, respectively, while the corresponding changes in the real average wage were $+5.6 \%,+1.1 \%$, and $-3.4 \% .^{5}$

The 2006-2008 minimum wage increases resulted from a lengthy campaign led by the Labor Party in the elections for the 17th Knesset (Israel's parliament). After the 2006 elections, the Labor Party became a key party in the governing coalition. Increasing the minimum wage and supporting “fair” earnings was one of Labor's pre-election commitments. ${ }^{6}$ There were no substantive changes in labor market

\footnotetext{
${ }^{3}$ The nominal increase is small relative to some increases in the U.S. minimum wage. For example, three increases from 2007-2009 raised the U.S. federal minimum wage by a cumulative $41 \%$ (nominal). However, U.S. minimum wage increases are much less frequent, with increases, in recent decades, only in 1990-91, 1996-97, and 2007-2009. Moreover, most of the U.S. evidence focuses on state minimum wage increases, which are often much smaller, with change of a few percent very common. For example, see the state minimum wage database at: http://www.economics.uci.edu/ dneumark/MW_LW\%20dataset\%20updated\%20through\%202019\%20-\%201-0120\%20Update.csv.

${ }^{4}$ There were frequent increases beginning in 2011. Our data only extend through 2016, but as Figure 1 shows, even a couple more years of data would not give us a post-period with a stable nominal minimum wage with which to study these later increases in the minimum wage.

${ }^{5}$ The real minimum wage and the real average wage is in NIS per month (deflated by the CPI), based on full-time work. The values measure changes within periods; for example the pre-period value is the change in the CPI deflated minimum wage between 2003Q1 and 2006Q1.

${ }^{6}$ The Labor Party's pre-election platform stated: “The challenge facing the Israeli society is to accelerate the processes of economic development and growth, and to ensure fair distribution to the public... The government, led
} 
developments in the period leading up to the election; Figure 2 shows the time-series of the unemployment and participation rates and the output gap. Moreover, Google trends data show that the minimum wage did not get much attention prior to the election or implementation of the increases (see Figure A1 in the online appendix). Hence, the increases in the minimum wage in this period can be viewed as stemming from political developments exogenous to labor market changes, and unlikely to have generated substantial changes in behavior prior to implementation. Nonetheless, in our analysis we are careful to compare developments in businesses more affected vs. businesses less affected by the minimum wage increase, even within industry, to net out any aggregate or sector-specific influences, and to rule out pre-trends associated with subsequent minimum impacts.

\section{Research on the Effects of Minimum Wages on Firms}

The literature on the effects of minimum wages on labor markets is voluminous, although most of it focuses on employment effects. Reviews covering employment, but also outcomes including poverty, the distribution of wages and income, skill accumulation, and prices, are provided in the books by Card and Krueger (1995), Neumark and Wascher (2008), and Belman and Wolfson (2014).

Although we know of no work that studies the incidence of minimum wages on business owners who might pay for higher minimum wages, and their position in the income distribution, the very limited literature on the effects of minimum wages on firms might provide some clues as to how minimum wages affect business income or profits, and for which businesses.

Card and Krueger (1995) do an event study of the effects of the 1990-1991 U.S. federal minimum wage increases and another proposed increase - and news stories related to them - on the daily excess returns of stock prices. The results of these analyses do not provide a clear indication that profits fall, although the authors note that the news events studied may not have provided much relevant information to market participants. This research applies to publicly-held firms, and does not provide direct evidence on the incomes of those affected by paying for higher minimum wages. Stocks are on average held by high-

by the Labor Party, will set a goal of reducing unemployment, raising minimum wage, effectively enforcing labor laws, reducing social gaps in income, education and housing quality.” 
income people, but they are also held by pension funds. ${ }^{7}$ Our analysis also faces the challenge of not being able to interpret data on the effects of minimum wages on the profits of publicly-held firms in terms of the incomes of owners, but we have data on both publicly-held and non-publicly-held firms.

Draca et al. (2011) provide more compelling evidence on the effects on firms, from an analysis of the 1999 introduction of the minimum wage in the United Kingdom, using firm-level profit data. They use pre-1999 information on the distribution of wages to measure differences in how firms are impacted, and find significant reductions in profitability. One of their data sets covers a wide range of firms, including smaller and medium-sized firms (and of course many firms not listed on the stock market), although some small firms are excluded. ${ }^{8}$ The negative effect of the minimum wage on profits is more evident for firms with more market power, which the authors argue is consistent with more competitive firms being more likely to pass on minimum wage increases to prices. However, this evidence does not map into how effects are distributed across the income distribution of business owners. ${ }^{9}$

Research on impact on small businesses is potentially informative about the distribution of minimum wage impacts across the income distribution of business owners, because the incomes of small business owners are likely to be considerably lower than those of other business owners. There appears to be a presumption that small businesses may be hit hardest by minimum wage increases. ${ }^{10}$ However, the empirical evidence is not so clear. The existing studies - Draca et al.’s (2011) analysis of residential care homes (which tend to be small), U.K. survey evidence in Mason et al. (2006), and Orazem and Mattila’s

\footnotetext{
${ }^{7}$ In the United States, direct stock ownership is concentrated in the top 1\% of the wealth distribution (53.4\% for 2016, vs. $40 \%$ in the next $9 \%$ and $6.8 \%$ in the bottom $90 \%$ ), while pension accounts are more equitably distributed, but still skewed to higher-wealth households (13.7\%, 51.2\%, and 35.2\%); see Wolff (2017, Table 10).

${ }^{8}$ A related analysis of data on U.K. residential care homes - a very low-wage sector - finds corroborating evidence. Machin and Wilson (2004) study the effects of the introduction of the U.K. minimum wage on closures of residential care homes, based on their own survey. They find some evidence of employment declines, but do not detect more closures among homes more impacted by the minimum wage.

${ }^{9}$ Belman and Wolfson (2014) review five additional studies of effects of minimum wages on profitability (or exits or failures). Waltman et al. (1998) and Orazem and Mattila (2002) report conflicting evidence on firms exits or failures ${ }^{10}$ For example, the U.S. Chamber of Commerce, in criticizing a proposed New Orleans living wage law in 2002, argued that "the mandated wage increases ... will hit small businesses the hardest" (https://www.uschamber.com/press-release/us-chamber-challenges-living-wage-law). And a website published by the Employment Policies Institute includes videos of small business owners claiming difficulties in adjusting to high minimum wages (https://www.facesof15.com/). U.S. minimum wage laws have long had a minimum sales or revenue threshold (https://www.dol.gov/whd/minwage/q-a.htm). Similarly, in Korea a large minimum wage hike in 2018 was accompanied by compensation to firms employing less than 30 workers (OECD, 2018).
} 
(2002) study of firms in services and retail newly covered by Iowa’s minimum wage law - do not ask whether minimum wage effects fell more heavily on small businesses. Luca and Luca (2019) use Yelp data to study the effects of minimum wages on restaurant closures. They find that more marginal restaurants (with lower ratings) disproportionately exit because of minimum wage increases, with no impact for the top-rated restaurants.

An exception is Chava et al. (2019), who use the National Establishment Time Series (NETS) to estimate the effects of minimum wage increases on establishment credit (Paydex) scores. They find that federal minimum wage increases in states where the federal minimum wage binds reduced credit scores and increased firm exit more for small establishments (below median sales in the 4-digit NAICS code). However, one can only draw an indirect inference from this evidence that lower-income business owners are more adversely affected by minimum wages.

\section{Data}

\section{Sources and key variables}

Our empirical analysis relies on administrative records of the Israeli Tax Authority. We match data from three sources - company records, employee data, and business owners - and measure family income for business owners and workers using these data. Our key variables are listed and defined in Table 1.

The first data source is annual company tax records covering 2003-2010, which provide data on each company's characteristics and indicators of business activity. The company files are used to construct annual profit measures, or corporate income from all sources, including reimbursement of the owner's salary. We use the inverse hyperbolic sine (IHS) of profits to accommodate zeroes and negative numbers (Ravallion, 2017). ${ }^{11}$ We measure the profit rate as corporate income divided by sales. Finally, we use the Central Bureau of Statistics (CBS) classification of economic sectors to define 23 sector dummy variables.

Our second data source is tax records of all employees for 2003-2010. The employee files provide data on each worker, including employment type, earnings, and number of months the employee worked at

\footnotetext{
${ }^{11}$ The interpretation of estimated coefficients of right-hand side variables when the dependent variable is expressed in terms of the IHS are nearly identical to the interpretation when the dependent variable is expressed in natural logs.
} 
the same job. Our tax records cover employees for whom pay is reported to tax authorities in Israel (i.e., for companies situated in Israel), and temporary employment abroad that is included in the payroll of an Israeli company. ${ }^{12}$ For each company, we match employees based on unique personal and company identifiers. We created the database at the employee level, matching workers to firms over time, and then calculated employee-related aggregates for each firm, including total employment.

Our research does not cover self-employed workers or employees related to them (in unincorporated businesses). In 2005, there were approximately 287,000 self-employed workers, representing $11.5 \%$ of employment, and 61,460 unincorporated businesses that employed 126,688 workers. The majority of these unincorporated businesses were very small, averaging around 2 employees per establishment. ${ }^{13}$ The minimum wage does not bind on wages or earnings of the self-employed themselves. And adding profits of unincorporated business is problematic since such businesses report income to the tax authority in a different manner than companies do; this, we study only incorporated companies. ${ }^{14}$

We use the data on employees to construct a critical variable for our analysis: the fraction affected $(F M W)$, which is the proportion of workers at a company earning below or equal to the minimum wage. We define FMW as the fraction of full-year employees working at their main job, in 2005 (the last year of the pre-treatment period), who were paid less than or equal to the monthly minimum wage that prevailed in the post-hike period (2009-2010). ${ }^{15}$ The data do not distinguish part-time vs. full-time workers, and earnings are reported monthly, not hourly. Thus, there is the potential for some measurement error in FMW, which would presumably attenuate our estimated effects of $F M W \cdot{ }^{16}$ However, we have taken a number of

\footnotetext{
${ }^{12}$ However, people who work abroad and their "center of life" is not in Israel (based on a given set of criteria such as presence in Israel, family location, etc.) are not liable for taxes in Israel, and hence are not included in the tax files.

${ }^{13}$ This is based on CBS data (https://old.cbs.gov.il/publications18/1673/pdf/t02_01.pdf); the figures are for 2010, as prior data regarding the self-employed are less reliable. There is a small number of larger unincorporated businesses of this kind (with tax records tying workers to the individuals who own the companies, rather than company identifiers).

${ }^{14}$ However, we compared monthly earnings of employees in unincorporated businesses to earnings in companies; excluding extreme values, earnings appear to be similarly distributed, suggesting that our results could be applicable to unincorporated businesses as well. See Figure A2 in the online appendix.

${ }^{15}$ The main job is the one that the worker chooses for the application of tax credits and benefits. In general, if an individual works in more than one job, defining the higher-paying job as the main job minimizes tax payments. ${ }^{16}$ Data from the 2005 Labor Force Survey (LFS) indicate that there is a 0.26 correlation between full-time work and employment above 10 months (the relevant variable available in the LFS), suggesting, as we would expect, that full-
} 
steps to mitigate this measurement error, and to document why we think it is second order. We base $F M W$ on full-year employees working at their main job because when we compared the Tax Authority earnings reports with those of the Central Bureau of Statistics (CBS), by industry, we found that the earnings of employees that worked full-year at the main job were closest to the wages that CBS reports; in other words, although not surprising, earnings in the tax data are much more similar to those of full-year workers. Moreover, we compared average wages and FMW derived from the tax data we use to those reported in the Income Survey (the equivalent of the U.S. Current Population Survey), by economic sector. Monthly wages and FMW rates are very similar by sector (see Figures A3 and A4 in the online appendix).

The third data source is a registry of company owners for 2003-2010, which includes ownership structure for each company and allows the identification of individual business owners. ${ }^{17}$ We identify owners (and their spouses, when present) of the companies in the sample for the year 2005. This is the most recent year before the minimum wage hike, and the year for which FMW was computed. Of the 57,520 companies in that year, we could identify data on 47,275 sole owners. ${ }^{18}$

We measure family incomes for both business owners and workers. We assembled data on owners' salary from the company, and from other sources, age, marital status, and spouse earnings. We also measure the percentile of each business owner's and worker's income in the overall distribution of income. ${ }^{19}$

year workers are more likely to work full-time. By basing FMW on full-year employees at their primary job (if applicable), we minimize the role of part-time workers who could create some measurement issues for FMW. ${ }^{17}$ Some of the companies are owned by other companies or foreign residents.

${ }^{18}$ This is out of a total of 63,674 owners, because of foreign ownership, firms that are owned by other local companies, and co-ownership. There were 2,010 companies that were fully owned by foreigners, and 2,414 that were fully owned by other companies. According to tax records, $60.5 \%$ of companies have a single owner, $29.1 \%$ have two owners, and the remainder have three or more owners.

${ }^{19}$ We study labor income rather than asset income. One problem with asset income is that wealthy individuals can hold large companies, which could post significant losses in given year (in the form of undistributed profits), resulting in low income ranks that would be misleading. Another potential measurement issue with business income is that firm owners could take money out of firms not just via profits but via expenses on depreciation. Depreciation expenditures in Israel follow a schedule of rates in the Income Tax Ordinance (Section 21). The depreciation rate is linear over the year and starts from the operation date of the property. The rate depends on the type of the property: e.g., $7 \%$ for machines and general equipment, $6 \%$ for furniture, and $1-2 \%$ for real estate. The low rates and limited period imply that depreciation is not an effective "tax avoidance" instrument. Regardless, "income" from this source would likely only make our results on incidence stronger since depreciation would depress measured profits of more-profitable 
There are two age-related issues regarding the measurement of family income. First, teens could not be matched to the parents, as tax records do not provide information beyond number of children in the household. Thus, family income includes incomes of the spouses, and teenagers' labor incomes are not included. However, teen employment is relatively low in Israel; the participation rate of youths (aged 1517 ) is $9.6 \%$, of whom only $1.5 \%$ are not in school. Correspondingly, according to the Income Survey only $7.2 \%$ of households had more than two providers in year 2005; and according to tax records, only 3.7\% of employees (including the self-employed) were younger than 19 in $2005 .{ }^{20}$ Among business owners, the tax records show that there was a single owner (i.e., one person) aged 18 in the year 2005, and owners below the age of 25 were fewer than 1\% of owners. Second, in the sample period military service in Israel was obligatory for men aged (18-21) and women aged (18-20, with some exceptions). Soldiers are counted as part of the labor force, but the army was excluded because it is in the government sector. (However, there is no restriction on ownership of companies by soldiers.)

\section{Sample}

To define our sample, we begin with data on all companies that were active in Israel from 2003 through 2010. ${ }^{21}$ The pre-period for our analysis of minimum wage effects begins in 2004; although our data start in 2003, the calculation of profits requires lagged data for carryover losses. The treatment period (2006-2008) was excluded from the estimation sample for most of our analyses, so we evaluate the evidence on changes from the 2004-2005 pre-period to the 2009-2010 post-period. We impose several restrictions to arrive at our analysis sample. ${ }^{22}$

We exclude the government sector and non-profit organizations, which we would expect to respond differently to minimum wages than do private-sector firms. Moreover, our interest is in the

firms. The data do not contain detailed profit and loss statements (including information on depreciation) for the vast majority of the companies in the sample (only for the largest ones).

${ }^{20}$ For the 2005 Income Survey, see https://old.cbs.gov.il/webpub/pub/text_page_eng.html?publ=11\&CYear=2005\&CMonth=1. For the tax records, see https://mof.gov.il/ChiefEcon/StateRevenues/StateRevenuesReport/DocLib/2005/Report2005_05.pdf.

${ }^{21}$ Firms that exit in 2010 are still included in the sample since the post-treatment period covers 2009-2010. Firms that exited in 2009 or earlier were excluded from the sample except for some robustness analyses described below.

${ }^{22}$ Table A1 in the online appendix shows how the sample size changes with these restrictions (and also reports some descriptive statistics on key measures, to show how these change with the sample restrictions.) 
incidence of minimum wages in relation to the income distribution of owners of firms, and the incomes of firm owners are most simply conceptualized and defined for private-sector firms. We exclude companies that were in the liquidation process at any point during our sample period. In principle, these liquidation events could be related to the minimum wage, leading us to potentially understate adverse effects of the minimum wage. However, such events could entail large employment or profit declines, and liquidation could be caused by quite different factors. We do not exclude publicly held companies, except where necessitated by the data. Our sample includes 144 publicly held companies in 2005, with 135 surviving through 2010.

Companies that are likely to be holding financial companies, based on extreme values of the profit rate, are also excluded. These companies can show extraordinarily high profits relative to sales (or employment) because of the nature of such companies, and because of ambiguities regarding where profits are assigned relative to where they are generated. ${ }^{23}$ We cannot directly identify holding companies, but when we explored extreme profit rate values for specific companies, we found that they were frequently of this type. ${ }^{24}$ Thus, we excluded observations with profit rates outside the range $-100 \%$ to $+100 \%$.

For companies established after 2005, we cannot measure FMW independently of employment or wage adjustments after minimum wage increases begin in 2006. Hence, we exclude these companies. Similarly, we exclude companies with no earnings data in 2005, for which we cannot measure $F M W{ }^{25}$ We believe our restrictions provide a sample that is informative about the effects of the minimum wage on private-sector firms that employ at least some minimum wage workers. Our sample period begins in 2004 with 55,159 companies (with 1,802,782 employees) and ends in 2010 with 43,553 companies (with 1,769,029 employees). The number declines because companies had to have been established by 2005 to be

\footnotetext{
${ }^{23}$ For example, the data include a company with three employees that reports revenues of a large construction company fully owned by it.

${ }^{24}$ We examined extreme values of profit rates to try to understand if these represent real activity or some recording technique, and found that the majority of companies with these extremes were holding companies - companies fully owned by business group owners without any economic activity beyond holding a portfolio of companies.

${ }^{25}$ As Table A1 in the online appendix shows, this excludes a fairly large number of companies. There are two reasons. First, there are some very small companies in terms of number of employees, with high labor turnover during the year. Second, until 2017 many companies were set up for tax purposes, which had earned profits but had not distributed them (effectively used as a tax shelter for various professionals due to higher personal income tax rates).
} 
included in our sample, and we lose companies through deaths but do not gain them through births. Descriptive statistics

Table 1 provides descriptive statistics on the key variables for our analysis sample. On average, in 2005 the average share of minimum wage workers across companies was $18 \%$. These workers were concentrated in fewer than half of all companies (the median value of $F M W$ is 0 ); $56 \%$ of companies had no minimum wage workers. ${ }^{26}$

Average profits of the firms in the sample were around 1.3 million NIS, with a much smaller median value (0.2 million NIS). Profits can be negative (or zero). Average profit rates of companies, calculated as profits divided by sales, were $15 \%$.

Average employment per firm was 36 workers. Large share of companies with FMW equal to $0 \%$ or $100 \%$ were firms with only one worker (the only values FMW can take on for these firms); $16.6 \%$ of firms with FMW equal to zero had only one worker, and 33.3\% of firms with $F M W$ equal to $100 \%$ had only one worker. ${ }^{27}$ Companies with FMW in the range $80-90 \%$ had the highest employment, averaging around 250 workers per firm (Figure 3). The companies in this group were, naturally, in economic sectors with large shares of minimum-wage workers (e.g., cleaning, security, and health services and social work).

\section{Effects on Employment and Profits}

In this section we first report some standard types of evidence on the effects of minimum wages on employment and earnings, and then move on to evidence on how the minimum wage affects company profits. The following section turns to the evidence on how the cost of minimum wage increases is distributed across the income distribution of business owners.

Minimum wage effects on earnings and employment

We want to be clear that countries with a national minimum wage - like Israel - pose more of a challenge for estimating minimum wage effects than countries with regional variation. We are using the

\footnotetext{
${ }^{26}$ Note that $F M W$ would likely be higher (and higher at more firms) if we could directly measure wages. There is no way to verify this directly, because if we expand the sample to workers other than full-year workers in their main job, we cannot map as reliably from earnings to wages (and hence $F M W$ ).

${ }^{27}$ Figure A5 in the online appendix shows the distribution of company-year observations in the estimation sample by FMW bins.
} 
Israeli data not to get a better estimate of the employment effect of the minimum wage, but rather to obtain evidence - non-existent in the minimum wage literature - on the incidence of the costs of minimum wages across the income distribution of business owners. That said, we try to obtain compelling evidence on effects on employment (and earnings), and our ability to do so is important because much of our evidence on effects on business owners uses the same identification strategy. Our identification exploits variation in effects for firms with different fractions of workers paid at or below the new, higher minimum in the period just before the minimum wage increases, denoted $F M W$. We do many analyses and alterations to our specifications to bolster the case that we are estimating a causal effect.

Figure 4 shows trends in average annual earnings, ${ }^{28}$ covering the pre-treatment, treatment, and post-treatment years, for workers in firms with very few minimum wage workers $(F M W \leq 10 \%)$, firms in the midrange $(40 \%<F M W \leq 75 \%)$, and firms with a high fraction of affected workers $(F M W>75 \%)$. We normalize to 2005 values. In the pre-treatment period, there is not much difference in the trends in average earnings at the three groups of firms; if anything earnings are growing slower at the firms with higher $F M W$. After the minimum wage increase, average earnings in lower-wage (higher $F M W$ ) firms grew faster, consistent with a direct effect of minimum wages on earnings. The initial relative increases are largest for the highest FMW firms, as we would expect. There is no evidence of a change in the trend for the low FMW firms.

Figure 5 presents a more granular disaggregation by FMW. In this figure, for earnings and employment, we report estimates from a regression of the percent change from 2004-2005 to 2009-2010 on dummy variables for FMW bins and firm fixed effects; the figure reports the FMW estimates (relative to $F M W=0 \%$ ). Average real earnings rose more from 2003-2005 to 2009-2010 in high FMW firms (the grey line), and the relationship with FMW is approximately monotonic. Figure 5 also presents evidence on employment changes (the black line), showing that employment fell among firms with a higher FMW (above around 20\%), but not at very low FMW firms. Moreover, among the higher FMW firms, the

\footnotetext{
${ }^{28}$ These are earnings associated with the main job position, but since we cover full-year employees on their main jobs, it is not unreasonable to think of these as wages. Still, to be as clear as possible we refer to earnings instead of wages.
} 
employment decline was generally sharper the higher FMW. The exception is at the very highest FMW firms, which we discuss below. The line labeled “combined” effect is the average earnings-weighted employment change. Given that earnings rose at more-affected (higher FMW) firms, this series declined by less than employment. With regard to effects on firm income, the employment declines suggested by Figure 5 will mitigate the costs of the higher minimum wage for more-affected firms; but this will also impact firm revenue and income.

To estimate the effects of minimum wages in a regression framework that allows for the variety of different analyses we perform, we begin with a simple difference-in-differences specification. Indexing firms by $i$, periods by $t$, and denoting firm-level controls (such as sector dummy variables) by $X$, we first estimate:

$$
\log (\text { Employment })_{i t}=\alpha+\beta F M W_{i}+\gamma P O S T_{t}+\delta F M W_{i} \times P O S T_{t}+X_{i} \lambda+\varepsilon_{i t}
$$

FMW has only an $i$ subscript, since it is defined at the firm level for the pre-treatment period. POST has only a period subscript, since it is a dummy variable for the post-treatment period. While we refer to FMW as a percent, in the regressions we define it on a $0-1$ scale. The estimate of $\delta$ from equation (1) is a difference-in-differences estimate of the effect of $F M W$ - the fraction affected by the minimum wage - on employment. We add sector dummy variables and their interactions with POST, to allow for differential changes in outcomes over time by sector that could be correlated with FMW, as well as firm fixed effects. The model is also augmented in other ways described below.

The results for employment, reported in Table 2, indicate a negative impact of the minimum wage increase on employment. The estimated coefficient of $\delta$ (on FMW $\times$ POST) in the first three columns, which exclude exiters, is negative and significant. The estimate is robust across the columns, which add firm fixed effects and then sector $\times$ POST interactions. The estimated elasticity from column (3) of Table 2 implies that for a company with FMW larger by 10 percentage points, the employment decline is $1.1 \%$ larger. Given that the mean of FMW is 0.18 , the implied elasticity is around -0.02 (approximately $1.1 /[(10 / 18) \times 100]$.) This is smaller than the central tendency of employment estimates (with respect to changes in the minimum wage) in the literature, which is in the range of -0.1 to -0.2 (Belman and 
Wolfson, 2019; Neumark and Shirley, 2021). However, that literature is nearly exclusively based on elasticities computed for workers, typically with a focus on workers likely to be strongly affected (like teens). Moreover, we do not weight in our analysis, since our goal is to study effects on business owners. For both of these reasons, we do not think there is a clear comparison to most estimates in the literature.

We explored whether there are changes in the pre-treatment period that look similar to changes in the treatment period, which would be evidence of spurious trends. We estimated an event-study regression for strongly treated $(F M W>0.4)$ and weakly treated $(F M W<0.1)$ firms, and found no differential in the pre-period, while the effect emerges over time in the post period; see Table 3, column (1). If anything, employment was growing faster at high FMW firms, although the estimated coefficient (Treatment $\times 2005)$ is not significantly different from zero. ${ }^{29}$

Another potential concern is that sectors with relatively high FMW were more adversely impacted by the global financial crisis, potentially leading to spurious evidence of adverse effects of minimum wages. This is not a concern. First, the financial crisis had a relatively modest effect in Israel, with the unemployment rate going up only 1.5 percentage points in 2009, and declining the next year (as Figure 2 shows). Second, the companies most affected were in the financial sector, and those that are export oriented. These are sectors where firms are generally not in the high FMW range, so if there was a bias it would be against finding adverse minimum wage effects. Moreover, the financial sector was already partially omitted based on our profit rate criterion. In addition, our model (in columns (2) and (3) of Table 2, and in most other specifications we report) includes sector $\times$ POST interactions, to control for differential changes by sector that could otherwise be confounded with minimum wage increases. In addition, we have run the models in Table 2 (and the tables that follow) excluding the financial and export-oriented sectors, and the results/estimates barely change; see Tables A2-A6 in the online appendix.

In Table 4, we report estimates from a less constrained model, where instead of using a linear measure of $F M W$, we break FMW into a number of categories. We show the estimates with and without the

${ }^{29}$ The same conclusion is evident from a plot of 2004 to 2005 employment growth against $F M W$, as shown in Panel A of Figure A6 in the online appendix. 
sector $\times$ POST interactions, but all columns include firm fixed effects. In columns (1) and (2) - column (2) includes the sector-POST interactions - the negative minimum wage effect on employment is increasing with $F M W$, except in the top range of $F M W>80 \%$.

Companies in the upper range of FMW are quite heterogeneous in terms of size and activity, with companies with very high FMW concentrated in different industries and much smaller (as noted earlier). In column (3) of Table 4 we therefore split the $F M W>80 \%$ range into two groups: $80 \%<F M W \leq 94 \%$ and FMW $>94 \%$. Companies with $80 \%<F M W \leq 94 \%$ are characterized by large employment, with 196.4 workers on average, while companies with $F M W>94 \%$ are much smaller, with average employment of 16.8. Moreover, among companies with $F M W>94 \%$, 32.9\% have only one worker; this percentage is $0.4 \%$ among companies with $80 \%<F M W \leq 94 \%$. The sectors also differ substantially. ${ }^{30}$ When, in column (3) of Table 4, we break up the $F M W>80 \%$ range this way, we find that only in the very top range (FMW $>94 \%$ ) is the employment effect not negative (and near zero). We believe this is because companies with such a high FMW share have less scope for adjusting employment. ${ }^{31}$ This conjecture about the inability of firms with very high FMW to adjust employment is consistent with two other pieces of evidence discussed below: that the highest FMW firms are more likely to exit as a result of the minimum wage increase; and that the profits of companies with very high FMW are reduced more strongly by the minimum wage increase. $^{32,33}$

We did one other potentially important robustness check, re-estimating the models for employment

\footnotetext{
${ }^{30}$ Companies in the lower range $(80 \%<F M W \leq 94 \%)$ are concentrated in wholesale and retail trade $(16 \%)$, cleaning and security (16\%), and health services and social work (12\%), while companies in the upper range (FMW $>94 \%)$ are highly concentrated in the latter industry (46\%), and also manpower (8\%) and business services (7\%).

${ }^{31}$ For companies with only one worker, which is common in this top FMW range, the inability to adjust employment is clear. For larger companies, the lack of employment response may reflect one of the Marshall-Hicks-Allen Laws of Labor Demand, in which under some conditions the elasticity of labor demand is smaller when labor's share is larger - in particular, when the elasticity of substitution is less than the elasticity of product demand (see, e.g., Hoffman, 2009). This carries over to the consideration of low-skilled labor as a separate input, and we might think that when the firm uses largely only one type of labor, the elasticity of substitution away from (low-skilled) labor is low.

${ }^{32}$ Table 4 does not provide an indication of relative employment growth at low FMW firms stemming from the minimum wage increase, which suggests there is not a large reallocation of labor from lower-wage to higher-wage firms. Longitudinally linked employee-employer data, which we do not have at this time, could provide more decisive evidence on whether some reallocation occurs, and where (by sector or by FMW).

${ }^{33}$ Tables A7 and A8 in the online appendix show the regressions corresponding to Tables 2 and 4 (for non-exiters) for earnings. Table A8 shows a clear increase (nearly monotonic) in the positive effect on earnings the higher is FMW.
} 
retaining the firms that exited before the post-period, setting their employment to zero, and using the IHS function instead of logs to accommodate the zero values. As shown in column (4) of Tables 2 and 4, we found stronger evidence of negative employment effects for higher values of $F M W$, consistent with the higher minimum wage doing more to increase firm exit. The estimates were a good deal more negative, which is not surprising given that the employment declines to zero can be very influential. In addition, in these specification we found a strong and significant negative effect for the highest FMW firms (FMW > $94 \%$ ), with an estimated coefficient of -0.212 (significant at the $1 \%$ level) - consistent with an inability to adjust employment, as discussed above, which reduces the ability of these firms to survive. ${ }^{34}$

\section{Minimum wage effects on profits}

We next turn to estimation of the effects of minimum wages on owners. We begin with the effects of minimum wages on profits. We begin with a similar specification to equation (1), but for profits:

$$
I H S(\pi)_{i t}=\alpha+\beta F M W_{i}+\gamma P O S T_{t}+\delta F M W_{i} \times P O S T_{t}+X_{i} \lambda+D_{\pi, b} \theta+D_{\pi, b} \times P O S T_{t} \eta+\varepsilon_{i t} .
$$

Aside from the different dependent variable, we also add a vector of dummy variables for initial profit quartiles ( $D_{\pi, b}$, see Table 1$)$ and their interactions with POST, to allow for differential changes associated with initial profits. We begin, in column (1) of Table 5, with the simplest specification, and in columns (2) and (3) we add sector dummy variables and their interactions with POST and firm fixed effects (as for employment in equation (1)). The estimate of $\delta$ from equation (2) is a difference-in-differences estimate of the effect of FMW - the fraction affected by the minimum wage - on profits.

The estimates in columns (1) and (2) indicate that profits decline in relative terms for firms with a higher value of FMW in the pre-treatment period. The negative estimates imply that a higher minimum wage reduces profits at firms with a high share of minimum wage workers, relative to firms with a low share. Since our sample does not include failed firms, the adverse effect of the minimum wage on higher

\footnotetext{
${ }^{34}$ We do not feature these estimates because, as discussed below, it is not clear how to define profits for firms that fail, and we wanted to focus on similar samples for the employment and profit results. See the next footnote for additional detail on the results for profits including exiters.
} 
FMW firms could be stronger than this estimate implies. ${ }^{35}$

Like for the analysis of employment, we explored whether we see changes in the pre-treatment period that look the same as the changes in the treatment period, which would be evidence of spurious trends. Turning back to Table 3, column (3), we actually find that profits were growing faster at high FMW firms (slope not significantly different from zero), which rules out the treatment effects on profits reflecting declining profits at high FMW firms in the pre-treatment period. ${ }^{36}$

To interpret the magnitude, given that in the regression FMW is defined on a scale of zero to one, the estimated coefficient of -0.749 on $F M W \times P O S T$ in Table 5, column (1) implies that profits declined by about $7.5 \%$ for firms where the fraction affected by the minimum wage, based on the pre-treatment period data, was about 10 percentage points higher. With the sector dummies and "trends" added, in column (2), this estimate becomes -0.795 , and with firm fixed effects the estimate is similar $(-0.720)$. These estimates appear to us to be sizable. For example, the latter estimate implies that profits of firms at the 90th percentile of $F M W$ decline by $21 \%$ more than profits of firms at the 75 th percentile of $F M W .{ }^{37}$ (We return to the other

\footnotetext{
${ }^{35}$ It is unclear how to treat exiters when studying profits. Assigning zero values for profits can be misleading since profits could have been negative before exiting, in which case exiters could appear more profitable relative to surviving firms than they actually are. In Table A9 in the online appendix, we therefore present the profit regressions in two alternative ways: including the exiters with profits equal to zero; and also setting the negative profits for survivors to zero, to avoid a making the exiters more profitable. We show that regardless of how we treat the data, there is a negative, sizable, and significant estimated coefficient of $F M W \times P O S T$.

A related point is that, especially if there is some exit of the most-affected firms, surviving firms could do better. Indeed, in a recent study of Germany's new minimum wage, Dustmann et al. (2019) find that affected workers have some tendency to move to higher-wage firms, consistent with reallocation towards more-productive firms, and they also find evidence that there is some firm exit (among small businesses) and that surviving firms became more productive. We estimated models for firm survival to the post-treatment period, and found that the most-affected firms were significantly less likely to survive (see Table A10 and Figure A7 in the online appendix). This implies that our evidence of declines in profits for affected firms understates the negative impact of the minimum wage on firms.

${ }^{36}$ Panel B in Figure A6 in the online appendix illustrates the same point. Looking at the three columns of Table 3, earnings dip more at the affected firms prior to the treatment. Typically we would be worried about the opposite - that if the post-treatment changes were in the same direction as the pre-treatment changes, the post-treatment changes may not be causal. Here, the opposite occurs, and then earnings rise at the most-affected firms as the minimum wage increase takes effect. We do not think there is a simple Ashenfelter dip based on random, mean-reverting declines in earnings at the most-affected firms in 2005 (relative to 2004), because earnings do not recover in the next year; rather, they begin to rise slowly, and monotonically, out through 2010. Moreover, the "proof is in the pudding," in the sense that if we just had an Ashenfelter dip/reversion to the mean in earnings, there would be no effect on employment and profits. As additional evidence, in Table A11 of the online appendix we show that the employment results are robust to dropping 2005, the year with the earnings dip in more-affected firms.

${ }^{37}$ The $75^{\text {th }}$ percentile of $F M W$ is 0.308 , and the $90^{\text {th }}$ percentile is 0.600 . Multiplying this difference by the estimated effect of -0.720 predicts a decline in profits of $21 \%$.
} 
columns of Table 5 later. $)^{38}$

While the estimated profit effect is large, we do not think it is extreme based on comparisons to other studies (although admittedly we have very little evidence to compare). Consider a 0\% vs. a 100\% FMW firm. Then labor costs go up at the latter by about $15 \%$ because of the minimum wage increase. Table 5 (column (3)) implies that the effect of the 100 percentage point change in $F M W$ reduces profits by $72 \%$. Draca et al. (2011) estimate roughly a 2.7 percentage point decline in the profit rate (about 27\%), from an induced wage increase of about $11 \%$. So our estimated effect scaled by the induced wage increase is in the same ballpark (72/15 vs. 27/11). Harasztosi and Linder (2019) estimate that where $100 \%$ of the workforce is affected, wages rose by 58\% (p. 2705), employment fell by about $8 \%$ (p. 2702), and the profit rate fell by around 30\% (p. 2711). So their effect on profits is smaller but not completely out of line with ours.

Moreover, the comparison may not be apt because we do not weight, following most of the literature, while Harasztosi and Linder do (see their footnote 12).

To provide a different way to convey the magnitude of the effect, we estimate a specification that measures the effect on profits of an estimate of the mechanical increase in labor costs from the minimum wage increase, based on the number of minimum wage workers in 2005 (the end of the pre-period). We modify equation (2) to be, instead:

$$
\begin{aligned}
\operatorname{IHS}(\pi)_{i t} & =\alpha+\beta \log \left(W B M W_{i}\right)+\gamma \log \left(R M W_{t}\right)+\delta \log \left(W B M W_{i}\right) \times \log \left(R M W_{t}\right)+X_{i} \lambda \\
& +D_{\pi, b} \theta+D_{\pi, b} \times P O S T_{t} \eta+\varepsilon_{i t} .
\end{aligned}
$$

In this specification, $\log (W B M I)$ is the log of the wage bill for minimum wage workers, computed as the number of minimum wage workers in 2005 multiplied by the statutory 2005 minimum wage, where minimum wage workers are defined as those below the deflated minimum wage in the post-period.

\footnotetext{
${ }^{38}$ Table 3 provides comparable estimates of the effects of the minimum wage on employment, earnings, and profits. In these estimates, and based on the last pre-treatment year (2005) and the last treatment year (2010), the own-wage elasticity for employment appears to be close to -1.3 , and the own-wage profit elasticity about -5 . However, these are not comparable to what is often estimated in the minimum wage literature, where the wage effect is calculated for wages of workers who remain employed; here, in contrast, we are estimating an earnings effect, which includes the employment effect. As a rough guide, if the "lost" employment were added back to earnings, with no other changes, the resulting wage elasticity would be roughly double, cutting these own-wage elasticities roughly in half.
} 
$\log (R M W)$ is the log of the relative minimum wage in the pre- and post-periods, defined as zero $(\log (1))$ for the pre-period and $\log (1.154)$ for the post-period, given the $15.4 \%$ increase in the minimum wage. The interaction therefore measures the percent change in profits for a one-percent higher effect of the minimum wage increase on the wage bill (based on minimum wage workers in 2005). ${ }^{39,40}$ Note that the increase in the wage bill we consider is a "mechanical" one, assuming no other adjustments in behavior. We expect the estimate to be negative but less than one in absolute value, as firms can adjust to the wage increase by varying employment, prices, and other variables.

The specification is otherwise the same as in Table 5 (and we estimated the model corresponding to column (3), including the sector dummies and their interactions with POST, and firm fixed effects). The estimated coefficient of the interaction is -0.269 (statistically significant at the $1 \%$ level), indicating that, for example, if the minimum wage increase implied a 10\% larger mechanical increase in the wage bill for minimum wage workers for a firm, its profits fell by $2.7 \% .{ }^{41}$ The implied effect is far less than one-for-one, consistent with the average FMW of 0.18 and with firms making other adjustments to offset the effects of the higher minimum wage (including, but not limited to, the reductions in employment among the lowestearning workers that we have already estimated). For example, there is evidence of some pass-through of minimum wages into prices (e.g., Aaronson, 2001, Lemos, 2008, and Ashenfelter and Jurajda, 2021), reductions in benefits - in particular, health insurance (Marks, 2011; Clemens et al., 2018a), potentially productivity increases (Coviello et al., 2020), and substitution towards higher-skilled labor (e.g., Clemens et al., 2018b).

A richer breakdown of firms into six bins based on FMW, paralleling our employment specifications, provides results that reinforce the conclusion that profits fell more at firms with larger shares of minimum wage workers (see Table 6). Compared with the zero FMW firms in the sample, the estimates

\footnotetext{
${ }^{39}$ This is not quite the same as the implied cost of topping off below-minimum wage workers to the minimum wage, and hence allows for some increases in wages to a bit above the minimum wage; on the other hand, it does not include potential spillovers to those initially above the new minimum wage, and hence should provide a reasonable back-ofthe envelope estimate of the cost of the minimum wage increase.

${ }^{40}$ While the inclusion of $\log \left(W B M W_{i}\right)$ in equation (3) helps explain the strategy, when we include firm fixed effects it is fully absorbed by them.

${ }^{41}$ The full regression results are in Table A12 in the online appendix.
} 
show that the minimum wage hike had little or no statistically significant effect on profits for the second and third bins $(0 \%<F M W \leq 40 \%)$. For companies with $F M W$ above $40 \%$, profits decline - for the fourth bin (40-60\%) by $20 \%$, for the fifth bin (60-80\%) by $44-45 \%$, and for the highest $F M W$ firms (80-100\%) by 87-92\%. Hence, the relationship is monotonic. The results are robust to allowing for different changes over time by economic sector (column (2)). As noted in the previous discussion of the employment results in Table 4, low labor adjustment in the top FMW firms can explain the larger negative impact on profits coupled with weaker evidence of employment declines at the firms with the very highest FMW.

Returning to Table 5, the remaining columns (4)-(7) report estimates for the effects of minimum wages on profits for the four quartiles of the profit distribution (based on the data from the period prior to the minimum wage increase) - from lowest to highest. We find the strongest negative impact of minimum wage on profits in the $1^{\text {st }}$ quartile of profits (including companies with losses or near-zero profits). The effect weakens significantly for firms in the $2^{\text {nd }}$ to $4^{\text {th }}$ quartiles. This evidence suggests that it is the lowprofit firms that bear most of the cost associated with higher minimum wages.

Effects by year

Our empirical results thus far compare the post- and pre-periods. To provide more information on the evolution of outcomes by year, Figure 6 graphs estimates of effects for earnings, employment, and IHS profits. The specifications (except for variation in the dependent variable) are the same as those in Tables 4 and 6, column (1), with the firm fixed effects included, although interacting the minimum wage variables with dummy variables for each year. We graph the interactions of the minimum wage variables with the dummy variable for each year from 2006-2010. For earnings, we see that the increases for the moreaffected firms began early and reached their maximum in the post-period (2009-2010). Employment at more-affected firms began to fall with the minimum wage increases, also reaching the lowest levels in the post-period for all groups except the highest FMW group (as discussed earlier). In the profits graph, the decline is persistent and clear for the three most-affected groups of firms (FMW between 40\% and 60\%, 
between $60 \%$ and $80 \%$, and between $80 \%$ and $100 \%){ }^{42}$

\section{Evidence on the Distribution of the Costs of Minimum Wage Increases}

We now turn to the evidence exploring how the incidence of the cost of minimum wage increases varies across the income distribution of business owners.

Minimum wage effects across the income distribution

We noted earlier that a more adverse effect of minimum wages on profits at relatively low-profit firms would likely also predict that a higher minimum wage has more adverse effects on business owners with relatively low incomes (“mom and pop” shops, among businesses). To explore this question directly, we alter our regression model to estimate the effects of minimum wages on profit not by $F M W$, but by the owners' income percentile in the overall income distribution (see Table 1 for variable definitions).

Denoting income percentile by $I P,{ }^{43}$ our regression model now becomes:

$$
I H S(\pi)_{i t}=\alpha+\beta I P_{i}+\gamma P O S T_{t}+\delta I P_{i} \times P O S T_{t}+X_{i} \lambda+\varepsilon_{i t} .
$$

We have substituted IP for FMW, to detect post-treatment changes in profits across the distribution of incomes of business owners. Note that $I P$ has only an $i$ subscript, since it is defined at the owner level, but only for the pre-treatment period.

The estimates of equation (4) are reported in Table 7, columns (1) and (2). Recall that a higher income percentile (IP) implies higher income of business owners. Thus, the positive estimated coefficients on the IP $\times$ POST interaction imply that profits of lower-income business owners declined more in relative terms in the post-treatment period. For example, the estimated coefficient of 2.351 in column (2) implies that firms with owners earning median income suffered a 7.6\% larger decline in profits than those at the

\footnotetext{
${ }^{42}$ It would be too messy to include confidence intervals in these figures. In the earnings graph, the standard errors for the estimates shown reach a maximum of about 0.013 , so nearly all of the estimates are significant (using, for this footnote, the $5 \%$ significance level). For the employment regressions, the standard errors for the estimates shown reach a maximum of about 0.022 , so again most of the estimates are significant. For the profit regressions, the standard errors are larger, reaching a maximum of about 0.123 . All of the estimates for the groups with FMW between $60 \%$ and $80 \%$, and between $80 \%$ and $100 \%$, are statistically significant, as are the estimates for firms with $F M W$ between $40 \%$ and $60 \%$ beginning in 2007 .

${ }^{43}$ The income percentiles are calculated based on universe of business owners and workers in 2005. Owners' income includes wages from owned business and other labor income.
} 
$75^{\text {th }}$ percentile. ${ }^{44}$ In columns (3) and (4) we report estimates of an expanded model disaggregating IP by the 10 deciles of the distribution, with the top decile as the reference category. The estimates indicate that the negative effect on profits is larger for the lower income business owners and the relationship is quite monotonic.

\section{Minimum wage incidence relative to the income distribution of business owners}

The implication of the preceding estimates is that profits of lower-income business owners were more adversely affected by the 2006-08 minimum wage increases. We already saw that profits (and employment) of higher FMW firms were also more adversely affected. Column (1) of Table 8 shows why these results coincide. Based on pre-treatment data - as is all the analysis in this subsection - the owners of businesses with higher FMW are lower in the income distribution. The relationship between $F M W$ and the income percentile of business owners is nearly monotonically negative. ${ }^{45}$

Note, though, that even among the high FMW firms, business owners are relatively high in the income distribution - for individuals, for example (column (1)), ranging from the $74^{\text {th }}$ to the $94^{\text {th }}$ percentile across different $F M W$ bins. Thus, this evidence suggests that the impact of minimum wage increases is regressive in terms of the income distribution of business owners, but still relatively progressive with regard to the overall distribution of income (and this would be more the case if, as seems likely, business owners have more assets because of the businesses they own).

To provide a richer perspective on distributional effects, column (2) shows the average income percentiles of workers, based on FMW - again, defined based on full-year workers - at the firms at which they were employed prior to the minimum wage increase. As we would expect, workers in higher FMW firms have lower incomes on average; the income percentile declines nearly monotonically with FMW.

Although our principle focus is on the incidence across the income distribution of business owners, the comparison between columns (1) and (2) is potentially of interest, showing that in the lowest FMW

\footnotetext{
${ }^{44}$ The median of $I P$ is 0.9516 , and the $75^{\text {th }}$ percentile is 0.9842 . Multiplying this difference by the estimated effect of 2.351 predicts a decline in profits of $7.6 \%$.

${ }^{45}$ We use pre-treatment ownership data to abstract from ownership and income changes that could result from the minimum wage hike.
} 
firms, workers' average income percentiles (77) are about the same as those of owners in the higher FMW firms (the percentiles range from 74 to 79 for firms with FMW above 60\%). In this sense, too, the redistributional impacts of the minimum wage seem, if not strictly regressive, than at least sharing the burden of the minimum wage very unequally between economic agents at similar points in the income distribution, with owners paying directly for the higher minimum wage, while workers with similar incomes do not. However, this evidence has to be interpreted cautiously, because we cannot measure the asset value of the firm, and owners may invest in their businesses in ways that lower reported income but increase the value of their business. On the other hand, incomes of workers in the high FMW firms are clearly lower than incomes of the owners of these firms, and in that sense the minimum wage does redistribute income downward.

In columns (3) and (4) of Table 8 we extend the analysis to family income - the usual lens through which we view redistribution, poverty, etc. Doing so amplifies the regressivity of the incidence of the minimum wage with respect to the distribution of incomes of business owners. Families with ownership of the highest FMW firms earn slightly less than the median family income in 2005 (column (3)), and the income percentiles for firms with FMW $>60 \%$ are not much above the median. Moreover, the income percentile declines significantly more, as FMW increases, in column (3) compared to column (1). ${ }^{46}$

Table 9 provides more details on the income distribution by FMW that includes family incomes (adding owners'/workers' spouses). Panel A shows the details for married business owners. ${ }^{47}$ Owners of high FMW businesses are younger, slightly more likely to be female, and have more children. The first two, at least, are almost certainly associated with lower income. As shown in column (5), average incomes of owners drop dramatically with FMW - and the contrast between lower FMW firms (e.g., FMW below 20\%)

\footnotetext{
${ }^{46}$ In addition, workers in the lowest $F M W$ firms are at higher income percentiles than business owners at the highest FMW firms. On the other hand, it is still very much the case that workers at high FMW firms are considerably lower in the family income distribution than workers at low FMW firms (column (4)). Thus, we might conclude that, overall, the effect of the minimum wage hike is fairly regressive for business owners (and even more so for families of business owners), but is progressive for workers (and even more so for families including minimum wage workers). ${ }^{47}$ Disaggregating by married and single provides income comparisons that do not depend on marital status. Among business owners, $85 \%$ are married, while the share of married workers is lower at $61 \%$. The comparison of single business owners/workers is shown in Table 10.
} 
and higher FMW firms (e.g., FMW above 30\%) is quite striking. Columns (9) and (10) show that incomes of spouses exacerbate the relationship between FMW and income, as incomes of spouses are higher for owners of low FMW firms, and hence the gaps in family income across the distribution of FMW are generally larger than for owner income alone (column (5) vs. (10)). The numbers in column (11) provide a summary measure showing this conclusion, indicating that family income declines quite sharply as FMW increases. These data reinforce the conclusion that, among business owners, the burden of the minimum wage falls on lower-income families.

Panel B of Table 9 shows that, as expected, average worker earnings decline with FMW (column (5)) - reflecting the fact that at high FMW firms most workers earn the minimum wage. This is reinforced by spouse's earnings, which also decline with FMW, indicating that incomes of spouses are positively correlated. However, spouses’ earnings do not decline nearly as steeply with FMW. Moreover, earnings of spouses of workers in high FMW firms are generally much higher, as reflected in the fact that average earnings of spouses of those in high FMW firms are much higher than those of the workers in these firms (column (8) vs. column (5)). This indicates that a large share of minimum wage workers are the secondary earners in families, which reduces the redistributional effects of minimum wages towards families with the lowest incomes. ${ }^{48}$ At the same time, a comparison of the family incomes of owners and workers in higher FMW firms - in column (10) of Panels A and B - indicates that the family incomes of minimum wage workers are much lower than those of the owners of high FMW firms. ${ }^{49}$

Analysis for singles, who constitute a much smaller share of the sample, provides similar results (see Table 10). As before, incomes of business owners and average earnings of workers decline with FMW. The main and obvious difference is that single owners and workers do not have the additional incomes of

\footnotetext{
${ }^{48}$ This parallels evidence for the United States, for example, that the high share of teens and young adults among minimum wage workers implies that a large share of the benefits of higher minimum wages do not go to poor families (Lundstrom, 2017).

${ }^{49}$ For example, in firms where FMW exceeds $90 \%$, average family income of owners is 198,334 NIS, vs. average family income of workers in those firms of 74,137 NIS. And the average family incomes of workers in low FMW firms are similar to the average family incomes of the owners of high FMW firms, implying that a large share of the cost of the minimum wage - for high FMW firms - falls heavily on one among two different types of agents (owners vs. workers), despite them having relative similar incomes, which is inconsistent with horizontal equity.
} 
spouses.

Thus, the conclusions from Table 9 (and 10) are similar to those from Table 8. The higher minimum wage does redistribute income towards lower-income families. But the redistribution is not from the top of the income distribution, but rather from owners whose incomes are higher than those of minimum wage workers, but whose incomes are lower than those of many other business owners who do not bear the burden of the minimum wage (and whose incomes are more similar to those of many higherearning workers).$^{50}$ Moreover, note that this distributional analysis does not account for profits of publiclyheld companies paid out as dividends (or reflected in appreciation of stocks). Since these companies are large and likely least affected by minimum wage increases, ${ }^{51}$ and stocks are held by higher-income individuals and families, our distributional analysis almost certainly understates the degree to which the burden of the minimum wage falls on lower-income business owners - making our evidence of the regressive nature of the burden of minimum wages, with respect to the income distribution among business owners, more striking.

\section{Conclusions}

In this paper, we study an unexplored dimension of the distributional effects of the minimum wage, turning attention from the question of the effects on workers, who are potentially helped by a higher minimum wage, to the question of who pays for it. A key goal of a higher minimum wage is income redistribution towards low-income families. Existing research on the minimum wage focuses on the impact on affected workers, but is largely silent on the incomes of the owners of businesses who pay for a higher minimum wage, and especially silent on the incidence of the costs of a higher minimum wage across the income distribution of business owners.

\footnotetext{
${ }^{50}$ A related issue, which we do not address here, is how minimum wages affect prices, since price changes affect the purchasing power of income changes. Indeed recent U.S. evidence in Renkin et al. (forthcoming) points to significant (actually, full) price pass-throughs of minimum wage increases, with the negative effects larger for poor families. Effects like these work against any progressive redistribution from the minimum wage. Related to this point, we would of course ideally like to measure effects on consumption (or utility) rather than income. We have no consumption data for business owners, or information on loans or sources of credit that might help smooth consumption.

${ }^{51}$ In the online appendix, Figure A8 shows the equivalent of Figure A5, but for publicly-traded companies. There are much lower shares of these companies in bins with high values of FMW.
} 
We study evidence on this dimension of the distributional effects of minimum wages using a unique administrative dataset on the universe of tax records for Israel, in the period surrounding a large and plausibly exogenous minimum wage increase. The evidence indicates that the minimum wage hike reduced profits of companies, with minimum-wage intensive companies bearing the bulk of the cost and adjusting their workforces more aggressively, and profits declining more for lower-income business owners. Moreover, owners of businesses with higher shares of minimum wage workers ranked at the bottom of the income distribution of business owners. In most cases, spouses of business owners earn less than the owners while spouses of minimum wage workers earn more, further reducing the redistributive effect of the minimum wage.

Overall, then, the evidence indicates that the higher minimum wage does redistribute income towards lower-income families. However, the redistribution is not from the top of the income distribution. Rather, it is from owners whose incomes are higher than those of minimum wage workers, but whose incomes are lower compared to other owners who do not bear the burden of the minimum wage.

Moreover, although not our main focus (in part because of data limitations), the incomes of owners most affected by minimum wage increases are similar to the incomes of many higher-earning workers. This implies that a large share of the cost of the minimum wage falls heavily on one among two different types of agents (owners of high FMW firms vs. workers at low FMW firms), despite them having relative similar incomes - inconsistent with horizontal equity.

Thus, minimum wages, while somewhat redistributive, are not effectively redistributing from the highest-income individuals or families. In that sense, the minimum wage is quite different from other redistributional policies financed by taxes - such as the U.S. Earned Income Tax Credit. ${ }^{52}$ We have no way of doing a direct comparison of the minimum wage with other redistributive tax policies, including simply more progressive taxation, in the absence of a structural model, so we do not, in this paper, quantify the

\footnotetext{
${ }^{52}$ There is also an EITC in Israel (see Brender and Strawczynski, 2019).
} 
differences in the distributional effects of the minimum wage and alternative policies. ${ }^{53}$ But our results clearly suggest that such an inquiry could be very useful (for Israel as well as other countries). Another policy that could be considered to improve the targeting of who pays for a higher minimum wage is to create a tax credit that offsets part of the cost of higher minimum wages borne disproportionately by the businesses that employ a relatively higher share of minimum wage workers (Neumark, 2019) - businesses that, as we have shown, have lower profits and are owned by those with lower incomes than the owners of other businesses.

${ }^{53}$ And of course our evidence on the regressive nature of the burden of higher minimum wages for business owners should be viewed alongside evidence, addressed in prior research, that minimum wages do not do a very good job of targeting benefits to low-income individuals or families. 


\section{References}

Aaronson, Daniel. 2001. "Price Pass-Through and the Minimum Wage.” Review of Economics and Statistics 83(1), pp. 158-69.

Ashenfelter, Orley, and Štěpán Jurajda. 2021. "Wages, Minimum Wages, and Price Pass-Through: The Case of McDonald's Restaurants.” Unpublished paper.

Belman, Dale, and Paul J. Wolfson. 2019. “15 Years of Research on U.S. Employment and the Minimum Wage.” LABOUR 33(4), pp. 488-506.

Belman, Dale, and Paul J. Wolfson. 2014. What Does the Minimum Wage Do? Kalamazoo, MI: Upjohn Press.

Brender, Adi, and Michel Strawczynski. 2019. “The EITC Program in Israel: Employment Effects and Evidence on Differential Impacts of Family vs. Individual-Income Based Design,” The Maurice Falk Institute for Research in Israel, Discussion Paper No. 19.04.

Card, David, and Alan B. Krueger. 1995. Myth and Measurement: The New Economics of the Minimum Wage. Princeton, N.J.: Princeton University Press.

Cengiz, Doruk, Arindrajit Dube, Attila Lindner, and Ben Zipperer. 2019. “The Effect of Minimum Wages on Low-Wage Jobs.” Quarterly Journal of Economics 134(3), pp. 1405-54.

Chava, Sudheer, Alexander Oettl, and Manpreet Singh. 2019. “Does a One-Size-Fits-All Minimum Wage Cause Financial Stress for Small Businesses?” NBER Working Paper No. 26523.

Choi, Hyunyoung, and Hal Varian. 2012. "Predicting the Present with Google Trends.” Economic Record 88, 2-9.

Clemens, Jeffrey, Lisa B. Kahn, and Jonathan Meer. 2018a. “The Minimum Wage, Fringe Benefits, and Worker Welfare.” NBER Working Paper No. 24635.

Clemens, Jeffrey, Lisa B. Kahn, and Jonathan Meer. 2018b. "Impacts of the Minimum Wage on Skill Requirements: Evidence from Vacancy Postings.” Discussion paper, Yale University.

Clymer, Adam. 1999. Edward M. Kennedy: A Biography. New York: William Morrow \& Co.

Coviello, Decio, Erika Desarranno, and Nicola Persico. 2020. “Minimum Wage and Individual Worker Productivity: Evidence from a Large U.S. Retailer.” Unpublished paper.

Draca, Mirko, Stephen Machin, and John Van Reenen. 2011. "Minimum Wages and Firm Profitability.” American Economic Review: Applied Economics 3(1), pp. 129-51.

Dube, Arindrajit. 2019. "Minimum Wages and the Distribution of Family Incomes.” American Economic Journal: Applied Economics 11(4), pp. 266-304.

Dube, Arindrajit. 2018. “Minimum Wages and the Distribution of Family Incomes.” NBER Working Paper No. 25240.

Dustmann, Christian, Attila Lindner, Uta Schönberg, Matthias Umkehrer, and Phillipp vom Berge. 2019.

"Reallocation Effects of the Minimum Wage: Evidence from Germany.” Unpublished manuscript. http://sarkoups.free.fr/dustmann719.pdf.

Harasztosi, Peter, and Attila Linder. 2019. “Who Pays for the Minimum Wage?” American Economic Review 109(8), pp. 2693-727.

Hoffman, Saul D. 2009. “Revisiting Marshall’s Third Law: Why Does Labor’s Share Interact with the Elasticity of Substitution to Decrease the Elasticity of Labor Demand?” Journal of Economic Education 40(4), pp. 437-45. 
Lemos, Sara. 2008. “A Survey of the Effects of the Minimum Wage on Prices.” Journal of Economic Surveys 22(1), pp. 187-212.

Luca, Dara Lee, and Michael Luca. 2019. "Survival of the Fittest: The Impact of the Minimum Wage on Firm Exit.” NBER Working Paper No. 25806.

Lundstrom, Samuel M. 2017. "When Is a Good Time to Raise the Minimum Wage?” Contemporary Economic Policy 35(1), pp. 29-52.

Machin, Stephen, and Joan Wilson. 2004. "Minimum Wages in a Low-Wage Labour Market: Care Homes in the UK.” Economic Journal 114: C102-9.

Marks, Mindy S. 2011. "Minimum Wages, Employer-Provided Health Insurance, and the NonDiscrimination Law.” Industrial Relations 50(2), pp. 241-62.

Mason, Colin M., Sara Carter, and Stephen K. Tagg. 2006. "The Effects of the National Minimum Wage on the UK Small Business Sector: A Geographical Analysis.” Environment and Planning C: Government and Policy 24(1), pp. 99-116.

Neumark, David. 2019. “The Higher Wages Tax Credit.” In Expanding Economic Opportunity for More Americans.” Melissa S. Kearney and Amy Ganz, eds. (Aspen, CO: The Aspen Institute Economic Strategy Group), pp. 196-212.

Neumark, David. 2016. "Policy Levers to Increase Jobs and Increase Income from Work after the Great Recession.” IZA Journal of Labor Policy, 5:6 (on-line).

Neumark, David, and Peter Shirley. 2021. "Myth or Measurement: What Does the New Minimum Wage Research Say about Minimum Wages and Job Loss in the United States?” NBER Working Paper No. 28388.

Neumark, David, and William Wascher. 2008. Minimum Wages. Cambridge, MA: MIT Press.

OECD. 2018. OECD Economic Surveys: Korea. June 2018.

Orazem, Peter F., and J. Peter Mattila. 2002. "Minimum Wage Effects on Hours, Employment, and Number of Firms: The Iowa Case.” Journal of Labor Research 23(3), pp. 3-23.

Piketty, Thomas, Emmanuel Saez, and Gabriel Zucman. 2018. "Distributional National Accounts: Methods and Estimates for the United States.” Quarterly Journal of Economics 133(2), pp. 553-609.

Ravallion, Martin. 2017. “A Concave Log-Like Transformation Allowing Non-positive Values.” Economics Letters 161, pp. 130-32.

Renkin, Tobias, Claire Montialoux, and Michael Siegenthaler. "The Pass-Through of Minimum Wages into U.S. Retail Prices: Evidence from Supermarket Scanner Data.” Forthcoming in Review of Economics and Statistics.

Sabia, Joseph J., and Robert B. Nielsen. 2015. "Minimum Wages, Poverty, and Material Hardship: New Evidence from the SIPP.” Review of Economics of the Household 13(1), pp. 95-124.

Waltman, Jerold, Allan McBride, and Nicole Camhout. 1998. "Minimum Wage Increases and the Business Failure Rate.” Journal of Economic Issues 32(1), pp. 219-23.

Wolff, Edward N. 2017. "Household Wealth Trends in the United States, 1962 to 2016: Has Middle Class Wealth Recovered?” NBER Working Paper No. 24085. 
Figure 1: Evolution of the Statutory Minimum Wage in Israel, 1998-2019

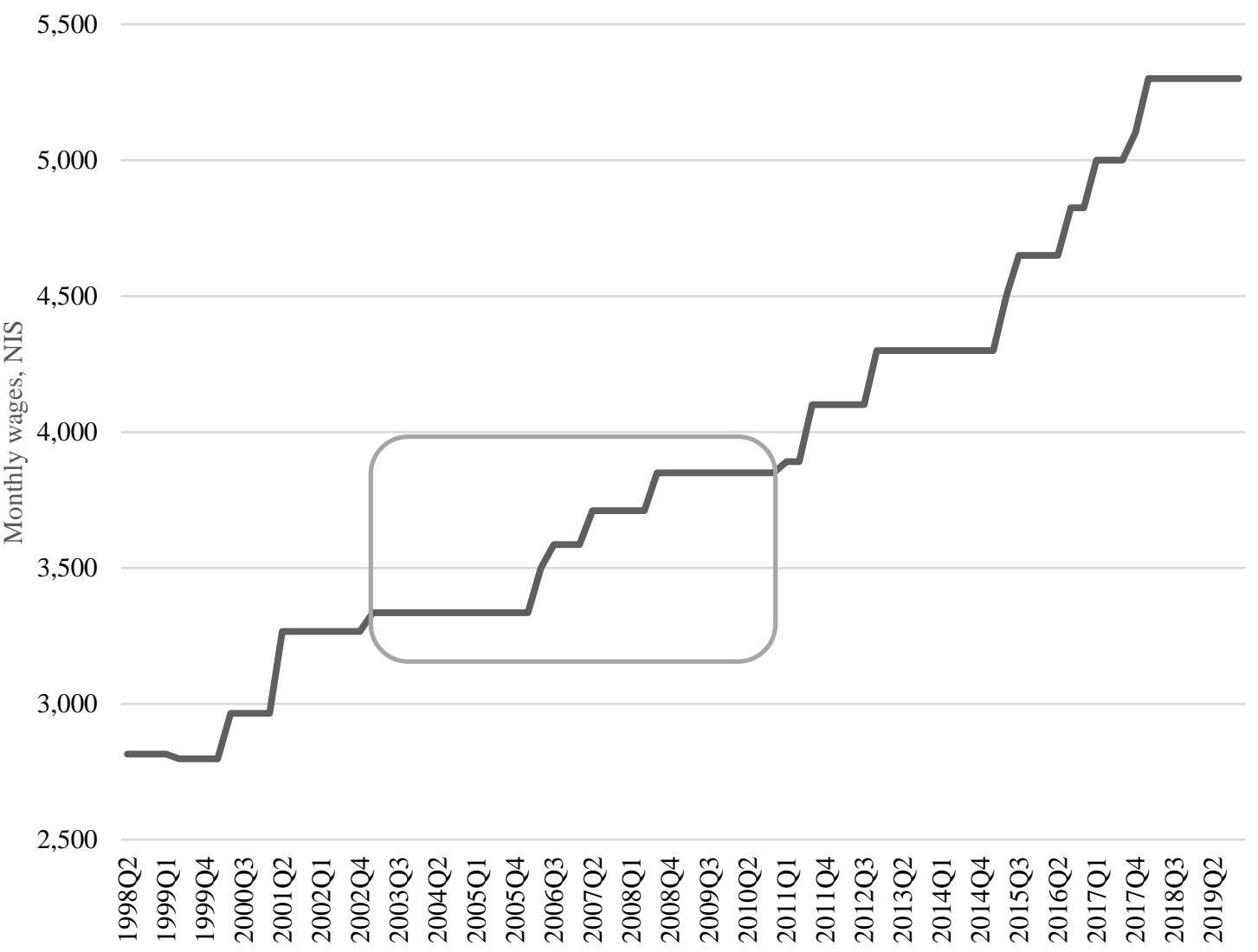

Notes: The minimum wage is in New Israeli Shekels (NIS) per month, at current prices, based on full-time work. The box shows the period covered by our analysis. 
Figure 2: Participation and Unemployment Rates (Population aged 15+), and Output Gap

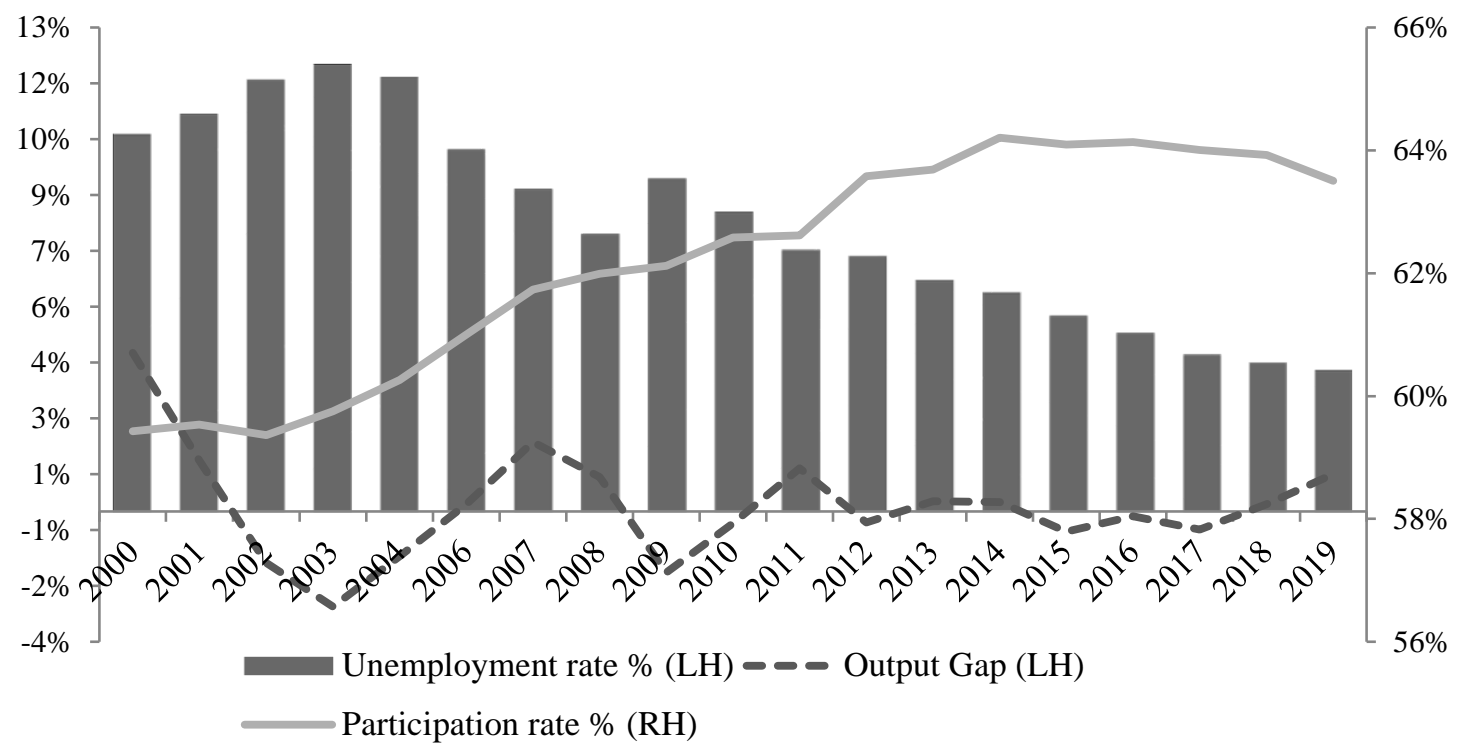

Source: For unemployment rate and participation rate: Central Bureau of Statistics (CBS), Labor Force Survey (LFS). We calculated the output gap by applying Hodrick-Prescott filter to quarterly national accounts series for GDP. Output Gap is calculated as part of the macroeconomic forecasting process in the Israeli Ministry of Finance and serves as a measure of slack in the economy. OECD publishes similar figures for the Israeli economy as part of the OECD Economic Outlook.

Figure 3: Employment per Firm, According to FMW Bins

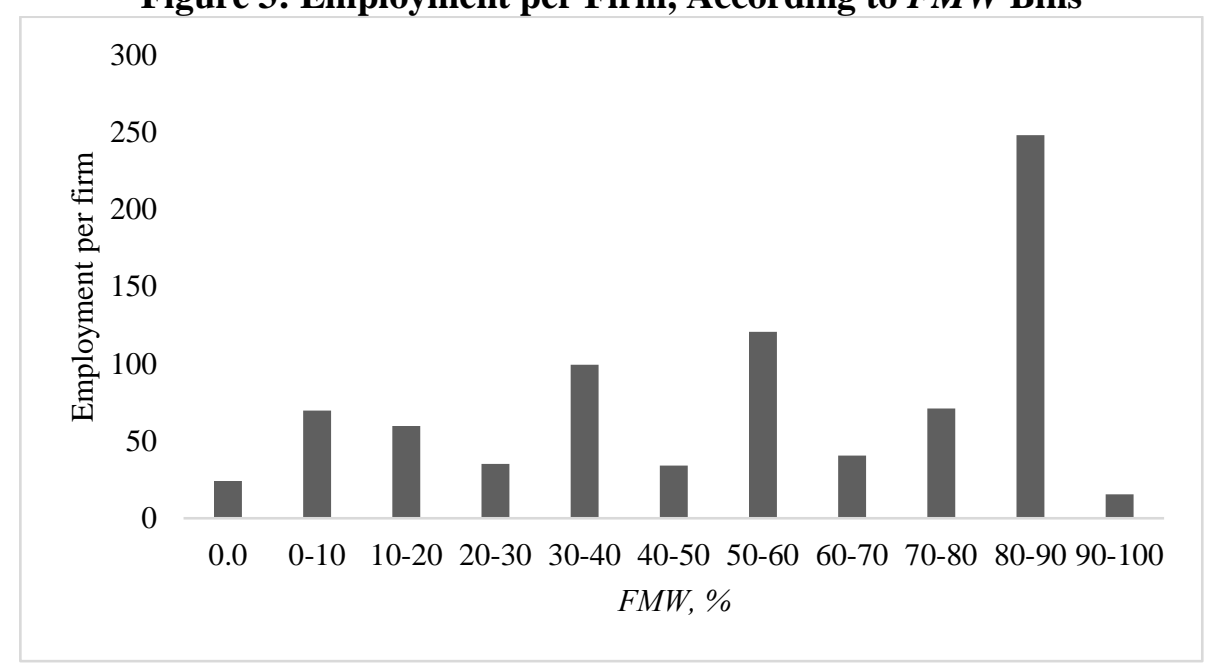


Figure 4: Earnings Trends for Workers in Firms with Low and High Initial Fractions of Minimum Wage (FMW) Workers, Normalized to Earnings in 2005, 2003-2010

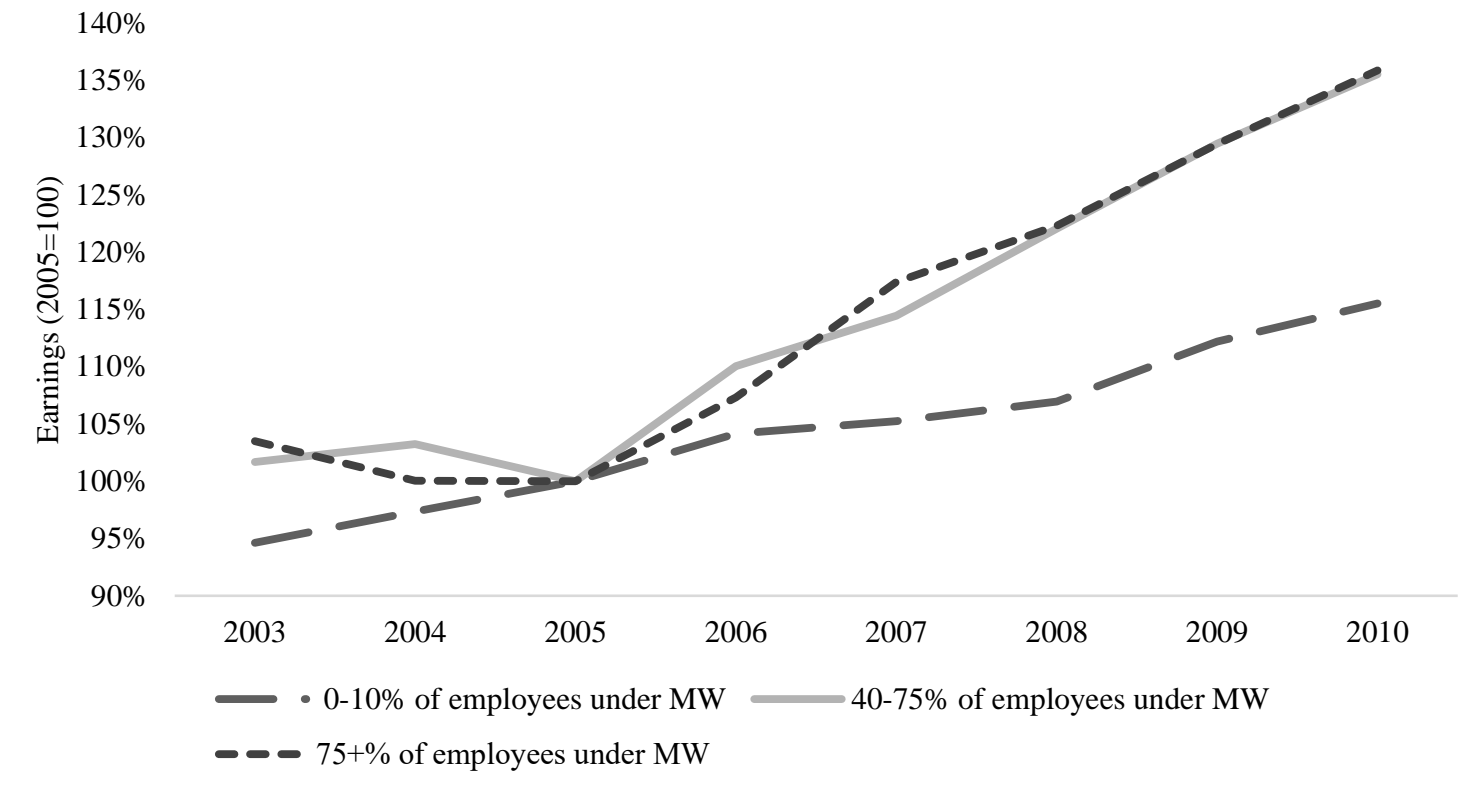

Note: Annual earnings in NIS normalized to earnings in 2005 for each group of workers based on FMW at their firms.

Figure 5: Employment and Average Real Earnings Changes following Minimum Wage Hike by FMW Bins, \% Change, 2004-2005 to 2009-2010

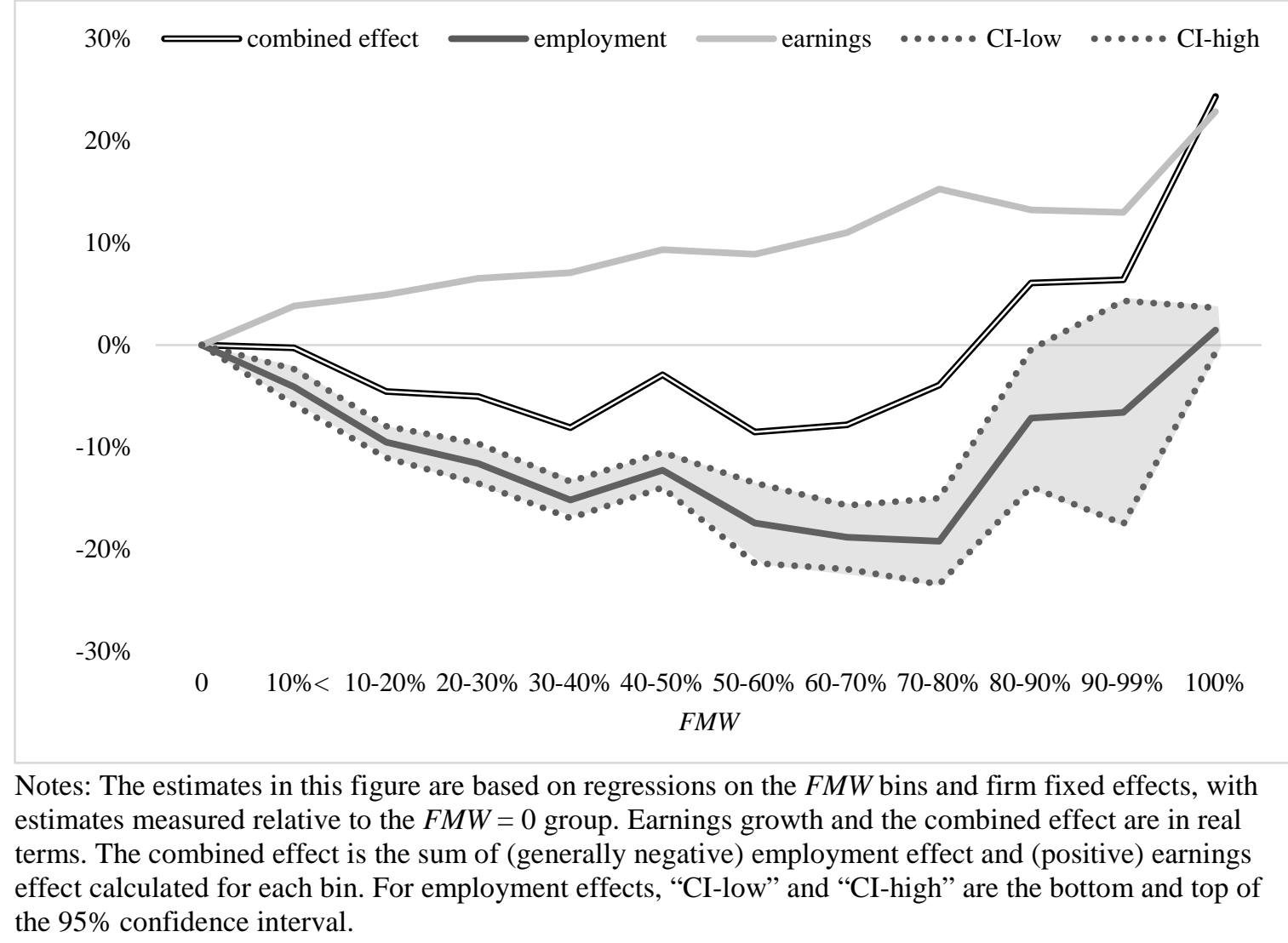


Figure 6: Estimated Effects on Earnings, Employment, and Profits by Year, 2006-2010

A. Log earnings

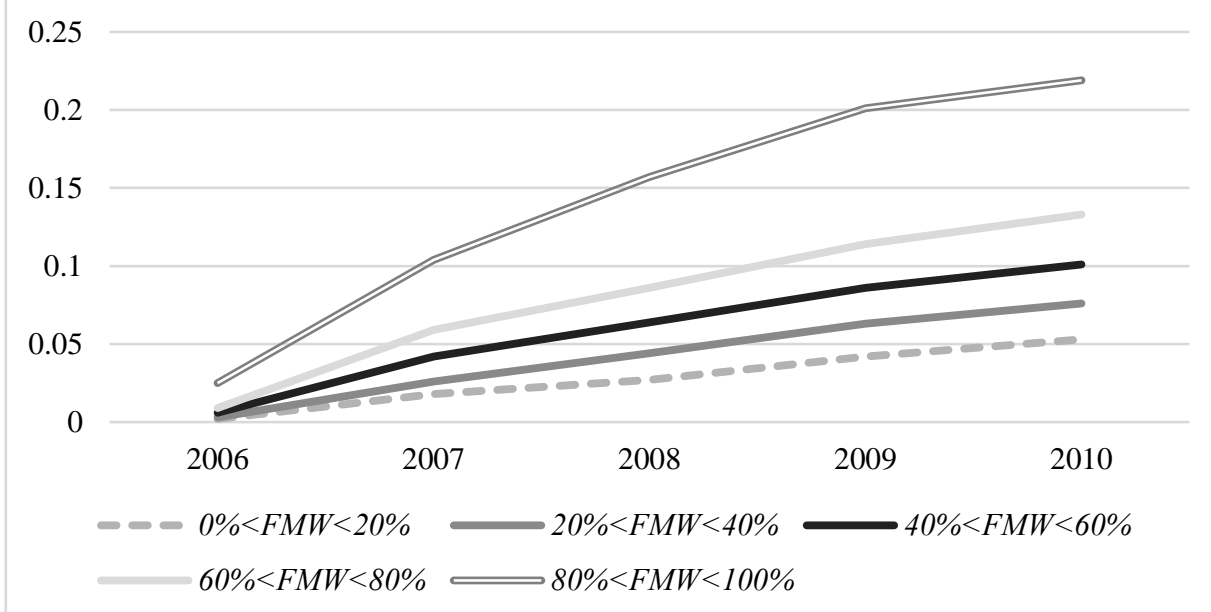

B. Log employment

0.05

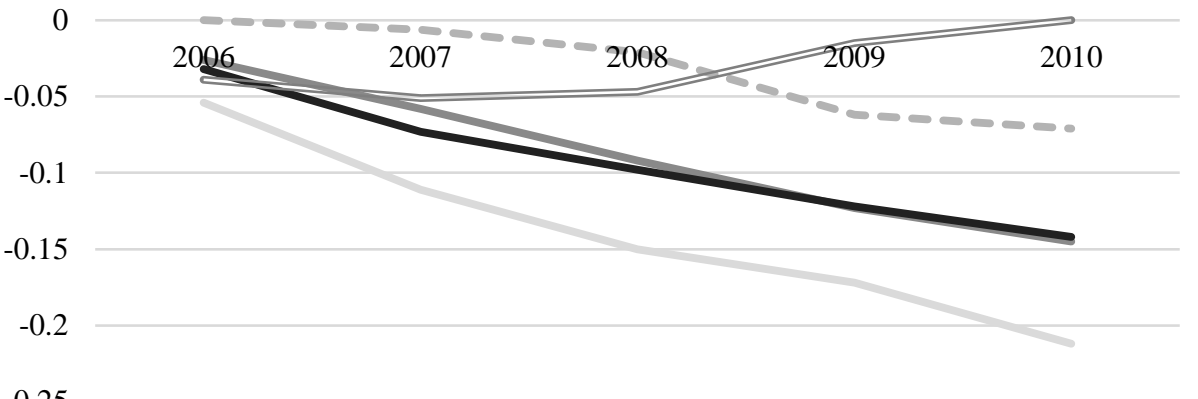

$-0.25$

$$
\begin{array}{r}
-0 \%<F M W<20 \% \quad 20 \%<F M W<40 \%-40 \%<F M W<60 \% \\
60 \%<F M W<80 \%=80 \%<F M W<100 \%
\end{array}
$$

\section{IHS Profits}

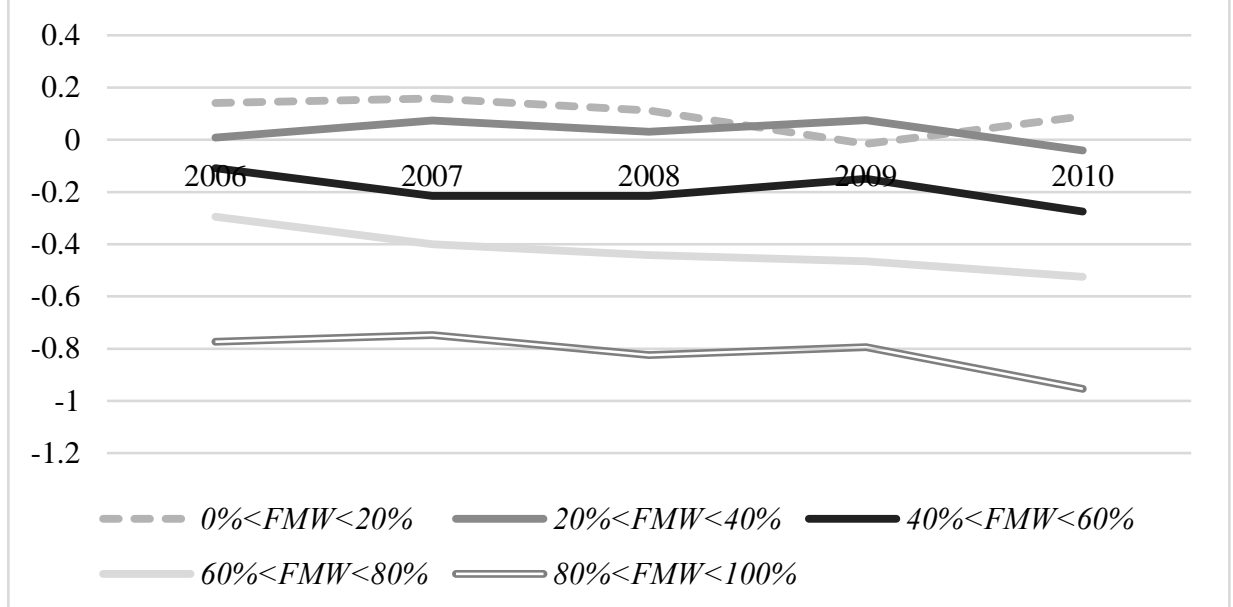

Note: Specifications correspond to Tables 4 and 6, column (1), except that we include dummy variables for each year rather than a simple POST variable. 
Table 1: Variables Used in Study and Descriptive Statistics of the Estimation Sample, 2004-2005 and 2009-2010

\begin{tabular}{|c|c|c|c|c|c|c|c|}
\hline Variable & Description & $\mathrm{N}$ & Median & Mean & Std. Dev. & Minimum & Maximum \\
\hline Profits, thousands NIS & $\begin{array}{l}\text { Taxable corporate income from all sources including } \\
\text { reimbursement of owner's salary (1,000's NIS/year) }\end{array}$ & 202,187 & 195 & 1,282 & 40,859 & $-1,610,081$ & $8,840,595$ \\
\hline$I H S(\pi)$ & $\begin{array}{l}\text { Inverse hyperbolic sine (IHS) transformation of corporate } \\
\text { income variable, defined as: } \\
\left.\sinh ^{-1} \text { (income }\right)=\log \left[\text { income }+\left(\sqrt{\text { income }^{2}+1}\right)\right]\end{array}$ & 202,187 & 5.95 & 4.11 & 4.80 & -14.98 & 16.69 \\
\hline Profit rate & Corporate income/sales (used for sample restriction) & 202,187 & 0.09 & 0.15 & 0.27 & -1.00 & 1.00 \\
\hline Initial profits quartiles: & $\begin{array}{l}\text { Dummy variables for quartiles of companies' profits in } \\
\text { the pre-period (2004-2005) }\end{array}$ & & & & & & \\
\hline Low & & 202,187 & 0 & 0.23 & 0.42 & 0 & 1 \\
\hline Medium-low & & 202,187 & 0 & 0.24 & 0.43 & 0 & 1 \\
\hline Medium & & 202,187 & 0 & 0.26 & 0.44 & 0 & 1 \\
\hline High & & 202,187 & 0 & 0.27 & 0.44 & 0 & 1 \\
\hline Employment & Employee headcount at the company level (main position) & 201,742 & 8.00 & 35.97 & 254.51 & 1 & 29,694 \\
\hline Log(employment) & Natural logarithm of employee headcount (main position) & 201,742 & 2.08 & 2.15 & 1.44 & 0.00 & 10.30 \\
\hline$F M W$ & $\begin{array}{l}\text { Fraction of employees paid monthly wages at or below } \\
\text { the post-hike minimum wage for } 2009-2010 \text { based only } \\
\text { on } 2005 \text { data on employees who worked continuously } \\
\text { throughout the full year on their main job; } 2005 \text { is the last } \\
\text { year before treatment; FMW is measured on a } 0-1 \text { scale } \\
\text { (although the charts present percentages for clarity) }\end{array}$ & 202,187 & 0 & 0.18 & 0.28 & 0 & 1 \\
\hline$P O S T$ & $\begin{array}{l}\text { Post-treatment dummy variable for years 2009-2010 (vs. } \\
\text { the 2004-2005 pre-treatment period) }\end{array}$ & 202,187 & 0 & 0.44 & 0.50 & 0 & 1 \\
\hline $\begin{array}{l}\text { Owners' income } \\
\text { percentile }(I P) \text { in } 2005\end{array}$ & $\begin{array}{l}\text { Percentiles of business owners' incomes in the total } \\
\text { income distribution of business owners and workers, in } \\
2005\end{array}$ & 58,384 & 95 & 90 & 15 & 0 & 100 \\
\hline $\begin{array}{l}\text { Workers income } \\
\text { percentile }(I P) \text { in } 2005\end{array}$ & $\begin{array}{l}\text { Percentiles of workers' incomes in the total income } \\
\text { distribution of business owners and workers, in } 2005\end{array}$ & $1,269,078$ & 48 & 48 & 28 & 0 & 99 \\
\hline $\begin{array}{l}\text { Weighted owners } \\
\text { income percentile by } \\
\text { company (IP) in } 2005\end{array}$ & $\begin{array}{l}\text { After calculating owners' income percentile (IP) in } 2005 \\
\text { at the individual-level, we calculated a weighted average, } \\
\text { by percentage of ownership, of IP for each company }\end{array}$ & 44,866 & 94 & 90 & 14 & 0 & 99 \\
\hline
\end{tabular}

NIS = New Israeli Shekels. We also define 23 sector dummy variables, for the following sectors: manufacturing; agriculture; high tech; electricity and water supply; construction; wholesale and retail trade; accommodation services and restaurants; transport and communications; financial institutions; real estate; computer and related activities; R\&D; manpower; security and cleaning; education; health services and social work; communities and other social and personal services; and other business activities. 
Table 2: Regression Estimates for Minimum Wage Effect on Log Employment, Based on Fraction Affected by Minimum Wage (FMW), 2004-2005 and 2009-2010

\begin{tabular}{|c|c|c|c|c|}
\hline & & & & $\begin{array}{l}\text { Including companies that } \\
\text { exit, IHS(employment) }\end{array}$ \\
\hline Variables & (1) & (2) & (3) & (4) \\
\hline$F M W$ & $\begin{array}{l}0.109^{* * *} \\
(0.022)\end{array}$ & $\begin{array}{c}-0.084^{* * *} \\
(0.020)\end{array}$ & $\ldots$ & $\ldots$ \\
\hline POST & $\begin{array}{l}0.068^{* * *} \\
(0.005)\end{array}$ & $\begin{array}{c}0.023 \\
(0.063)\end{array}$ & $\begin{array}{l}-0.057 \\
(0.058)\end{array}$ & $\begin{array}{l}-0.587^{* * *} \\
(0.073)\end{array}$ \\
\hline$F M W \times P O S T$ & $\begin{array}{c}-0.122^{* * *} \\
(0.019) \\
\end{array}$ & $\begin{array}{c}-0.098^{* * *} \\
(0.018) \\
\end{array}$ & $\begin{array}{l}-0.114^{* * *} \\
(0.013) \\
\end{array}$ & $\begin{array}{l}-0.368^{* * *} \\
(0.021)\end{array}$ \\
\hline $\begin{array}{l}\text { Sector dummies and sector } \\
\text { dummies } \times P O S T\end{array}$ & no & yes & yes & yes \\
\hline Firm fixed effects & no & no & yes & yes \\
\hline $\mathrm{R}^{2}$ & 0.001 & 0.118 & 0.925 & 0.863 \\
\hline $\mathrm{N}$ & 201,742 & 201,742 & 201,742 & 224,932 \\
\hline
\end{tabular}

Notes: Dependent variable is $\log ($ employment) per firm in each year (IHS(employment) in (4)). Levels of significance: $10 \%^{*}, 5 \%^{* *}, 1 \%^{* * *}$. Standard errors are clustered at the firm level. FMW is measured on a $0-1$ scale in the regressions. We use IHS(employment) because of the zero values for exiting companies in (4). Three dots (...) indicates that the variable is absorbed by the firm fixed effects.

Table 3: Event-Study Regression Estimates for Minimum Wage Effects, Based on High vs. Low Fraction Affected by Minimum Wage (FMW), 2004-2010

\begin{tabular}{|l|c|c|c|}
\hline & $(1)$ & $(2)$ & $(3)$ \\
Variables & Ln(employment) & Ln(earnings) & IHS $(\pi)$ \\
\hline Treatment $\times 2005$ & -0.006 & $-0.076^{* * *}$ & $0.130^{* * *}$ \\
$($ pre-trend $)$ & $(0.006)$ & $(0.003)$ & $(0.028)$ \\
\hline Treatment $\times 2006$ & $-0.042^{* * *}$ & $-0.027^{* * *}$ & $-0.267^{* * *}$ \\
& $(0.007)$ & $(0.004)$ & $(0.050)$ \\
\hline Treatment $\times 2007$ & $-0.080^{* * *}$ & $0.022^{* * *}$ & $-0.313^{* * *}$ \\
& $(0.008)$ & $(0.005)$ & $(0.053)$ \\
\hline Treatment $\times 2008$ & $-0.100^{* * *}$ & $0.052^{* * *}$ & $-0.357^{* * *}$ \\
& $(0.009)$ & $(0.005)$ & $(0.056)$ \\
\hline Treatment $\times 2009$ & $-0.106^{* * *}$ & $0.079^{* * *}$ & $-0.319^{* * *}$ \\
& $(0.010)$ & $(0.006)$ & $(0.058)$ \\
\hline Treatment $\times 2010$ & $-0.119^{* * *}$ & $0.094^{* * *}$ & $-0.456^{* * *}$ \\
& $(0.011)$ & $(0.006)$ & $(0.060)$ \\
\hline Year fixed effects & yes & yes & yes \\
\hline Firm fixed effects & yes & yes & yes \\
\hline Initial profits dummies and & no & no & yes \\
initial profits $\times$ POST & & & 0.625 \\
\hline $\mathrm{R}^{2}$ & 0.924 & 0.880 & 283,355 \\
\hline $\mathrm{N}$ & 282,579 & 282,579 & y \\
\hline $\mathrm{N}$ & & & \\
\hline
\end{tabular}

Notes: Dependent variables are $\log ($ employment), $\log ($ earnings), and IHS $(\pi)$ per firm in each year. Levels of significance: $10 \%{ }^{*}, 5 \%^{* *}, 1 \%{ }^{* * *}$. Standard errors are clustered at the firm level. $F M W$ is measured on a $0-1$ scale in the regressions. Treatment group defined as a dummy variable equal to 1 if $F M W>40 \%$ (affected firms) and 0 if $F M W<10 \%$ (unaffected firms). The sample is restricted to these FMW categories, but there are more observations than in Table 2 because 2006-2008 observations are included. The main treatment effect is absorbed by the firm fixed effects, and the treatment $\times$ year interactions are relative to 2004 . 
Table 4: Regression Estimates for Minimum Wage Effect on Log Employment, with Separate FMW Bins, 2004-2005 and 2009-2010

\begin{tabular}{|c|c|c|c|c|}
\hline & & & & $\begin{array}{l}\text { Including companies that } \\
\text { exit, IHS(employment) }\end{array}$ \\
\hline Variables & (1) & (2) & (3) & (4) \\
\hline POST & $\begin{array}{l}0.029^{* * *} \\
(0.004)\end{array}$ & $\begin{array}{l}-0.035 \\
(0.049) \\
\end{array}$ & $\begin{array}{l}-0.034 \\
(0.049)\end{array}$ & $\begin{array}{c}-0.569^{* * *} \\
(0.073)\end{array}$ \\
\hline $\begin{array}{l}F M W>0-20 \% \times \\
P O S T\end{array}$ & $\begin{array}{l}-0.072^{* * *} \\
(0.009)\end{array}$ & $\begin{array}{c}-0.072^{* * *} \\
(0.009)\end{array}$ & $\begin{array}{l}-0.072^{* * *} \\
(0.009)\end{array}$ & $\begin{array}{l}-0.048^{* * *} \\
(0.018)\end{array}$ \\
\hline $\begin{array}{l}\text { FMW } 20-40 \% \times \\
\text { POST }\end{array}$ & $\begin{array}{l}-0.135^{* * *} \\
(0.010)\end{array}$ & $\begin{array}{l}-0.132^{* * *} \\
(0.010)\end{array}$ & $\begin{array}{c}-0.132^{* * *} \\
(0.010)\end{array}$ & $\begin{array}{l}-0.169^{* * *} \\
(0.019)\end{array}$ \\
\hline $\begin{array}{l}\text { FMW } 40-60 \% \times \\
P O S T\end{array}$ & $\begin{array}{c}-0.130^{* * *} \\
(0.013)\end{array}$ & $\begin{array}{c}-0.126^{* * *} \\
(0.013)\end{array}$ & $\begin{array}{c}-0.127^{* * *} \\
(0.013)\end{array}$ & $\begin{array}{l}-0.252^{* * *} \\
(0.022)\end{array}$ \\
\hline $\begin{array}{l}\text { FMW } 60-80 \% \times \\
\text { POST }\end{array}$ & $\begin{array}{l}-0.190^{* * *} \\
(0.021)\end{array}$ & $\begin{array}{l}-0.184^{* * *} \\
(0.021)\end{array}$ & $\begin{array}{c}-0.184^{* * *} \\
(0.021)\end{array}$ & $\begin{array}{l}-0.475^{* * *} \\
(0.038)\end{array}$ \\
\hline $\begin{array}{l}\text { FMW } 80-100 \% \times \\
\text { POST }\end{array}$ & $\begin{array}{c}0.005 \\
(0.016)\end{array}$ & $\begin{array}{c}0.006 \\
(0.016)\end{array}$ & & \\
\hline $\begin{array}{l}\text { FMW } 80-94 \% \times \\
\text { POST }\end{array}$ & & & $\begin{array}{l}-0.062^{*} \\
(0.037)\end{array}$ & $\begin{array}{c}-0.691^{* * *} \\
(0.138)\end{array}$ \\
\hline $\begin{array}{l}\text { FMW 94-100\% } \times \\
\text { POST }\end{array}$ & & & $\begin{array}{c}0.014 \\
(0.435)\end{array}$ & $\begin{array}{l}-0.212^{* * *} \\
(0.024)\end{array}$ \\
\hline $\begin{array}{l}\text { Sector dummies and } \\
\text { sector dummies } \times \\
\text { POST }\end{array}$ & no & yes & yes & yes \\
\hline Firm fixed effects & yes & yes & yes & yes \\
\hline $\mathrm{R}^{2}$ & 0.925 & 0.926 & 0.926 & 0.862 \\
\hline $\mathrm{N}$ & 201,742 & 201,742 & 201,742 & 224,932 \\
\hline
\end{tabular}

Notes: Dependent variable is log(employment) per firm in each year (IHS(employment) in column (4)). Levels of significance: $10 \%{ }^{*}, 5 \%^{* *}, 1 \%{ }^{* * *}$. Standard errors are clustered at the firm level. $F M W$ is measured on a $0-1$ scale in the regressions. Specification (3) splits the top FMW $80-100 \%$ bin into two groups that are more homogenous, as explained in the text. The main effects of the $F M W$ bins are absorbed by the firm fixed effects. The $F M W \times P O S T$ interactions are relative to $F M W 0 \%$. IHS(employment) is used in column (4) because of the zero values for exiting companies. 
Table 5: Regression Estimates of Minimum Wage Effect on Profits (IHS( $\pi$ )), Based on Fraction Affected by Minimum Wage (FMW), 2004-2005 and 2009-2010

\begin{tabular}{|c|c|c|c|c|c|c|c|}
\hline Variables & $(1)$ & $(2)$ & (3) & (4) & (5) & (6) & (7) \\
\hline & Full sample & Full sample & Full sample & $\begin{array}{l}\text { Sample: low } \\
\text { initial profits }\end{array}$ & $\begin{array}{l}\text { Sample: medium } \\
\text { low initial profits }\end{array}$ & $\begin{array}{l}\text { Sample: medium } \\
\text { initial profits }\end{array}$ & $\begin{array}{l}\text { Sample: high initial } \\
\text { profits }\end{array}$ \\
\hline$F M W$ & $\begin{array}{l}0.155^{* * *} \\
(0.022) \\
\end{array}$ & $\begin{array}{l}0.179^{* * *} \\
(0.023)\end{array}$ & $\ldots$ & $\ldots$ & $\ldots$ & $\ldots$ & .. \\
\hline$P O S T$ & $\begin{array}{c}-1.416^{* * *} \\
(0.034)\end{array}$ & $\begin{array}{c}-2.022^{* * *} \\
(0.224)\end{array}$ & $\begin{array}{c}-2.017^{* * *} \\
(0.227)\end{array}$ & $\begin{array}{c}4.603^{* * *} \\
(0.503)\end{array}$ & $\begin{array}{c}-1.330^{* * *} \\
(0.354)\end{array}$ & $\begin{array}{c}-1.668^{* * *} \\
(0.387)\end{array}$ & $\begin{array}{c}-1.841^{* * *} \\
(0.553)\end{array}$ \\
\hline$F M W \times P O S T$ & $\begin{array}{c}-0.749^{* * *} \\
(0.068)\end{array}$ & $\begin{array}{c}-0.795^{* * *} \\
(0.070)\end{array}$ & $\begin{array}{c}-0.720^{* * *} \\
(0.070)\end{array}$ & $\begin{array}{c}-1.805^{* * *} \\
(0.152)\end{array}$ & $\begin{array}{l}-0.172^{*} \\
(0.105) \\
\end{array}$ & $\begin{array}{c}-0.362^{* *} \\
(0.123) \\
\end{array}$ & $\begin{array}{c}0.026 \\
(0.167) \\
\end{array}$ \\
\hline $\begin{array}{l}\text { Initial profits } \\
\text { dummies }\end{array}$ & yes & yes & yes & no & no & no & no \\
\hline Initial profits $\times P O S T$ & yes & yes & yes & no & no & no & no \\
\hline $\begin{array}{l}\text { Sector dummies and } \\
\text { sector dummies } \times \\
P O S T \\
\end{array}$ & no & yes & yes & yes & yes & yes & yes \\
\hline Firm fixed effects & no & no & yes & yes & yes & yes & yes \\
\hline $\mathrm{R}^{2}$ & 0.551 & 0.554 & 0.732 & 0.641 & 0.471 & 0.465 & 0.483 \\
\hline $\mathrm{N}$ & 202,187 & 202,187 & 202,187 & 47,146 & 48,082 & 52,332 & 54,627 \\
\hline
\end{tabular}

Notes: Dependent variable is $I H S(\pi)$ per firm in each year. Levels of significance: $10 \%^{*}, 5 \%{ }^{* *}, 1 \%{ }^{* * *}$. Standard errors are clustered at the firm level. FMW is measured on a 0-1 scale in the regressions. Three dots (...) indicates that the variable is absorbed by the firm fixed effects. 
Table 6: Regression Estimates of Minimum Wage Effect on Profits $(I H S(\pi))$, Based on Fraction Affected by Minimum Wage (FMW), with Separate FMW Bins, 2004-2005 and 2009-2010

\begin{tabular}{|l|c|c|}
\hline Variables & $(1)$ & $(2)$ \\
\hline POST & $-1.431^{* * *}$ & $-2.088^{* * *}$ \\
& $(0.037)$ & $(0.227)$ \\
\hline FMW $>0-20 \% \times$ POST & 0.015 & $0.098^{*}$ \\
& $(0.059)$ & $(0.059)$ \\
\hline FMW 20-40\% × POST & -0.004 & 0.032 \\
& $(0.056)$ & $(0.056)$ \\
\hline FMW 40-60\% × POST & $-0.201^{* * *}$ & $-0.197^{* * *}$ \\
& $(0.064)$ & $(0.065)$ \\
\hline FMW 60-80\% $\times$ POST & $-0.438^{* * *}$ & $-0.451^{* * *}$ \\
& $(0.105)$ & $(0.106)$ \\
\hline FMW 80-100\% $\times$ POST & $-0.874^{* * *}$ & $-0.924^{* * *}$ \\
& $(0.084)$ & $(0.085)$ \\
\hline Initial profit dummies & yes & yes \\
\hline Initial profit dummies $\times$ POST & yes & yes \\
\hline Sector dummies and sector dummies $\times$ POST & no & yes \\
\hline Firm fixed effects & yes & yes \\
\hline R & 0.730 & 0.732 \\
\hline N & 202,187 & 202,187 \\
\hline
\end{tabular}

Notes: Dependent variable is $\operatorname{IHS}(\pi)$ per firm in each year. Levels of significance: $10 \%^{*}, 5 \%^{* *}, 1 \%^{* * *}$. Standard errors are clustered at the firm level. The main effects of the $F M W$ bins are absorbed by the firm fixed effects. The $F M W \times P O S T$ interactions are relative to $F M W 0 \%$. IHS(employment) because of the zero values for exiting companies. 
Table 7: Regression Estimates of Minimum Wage Effect on Profits (IHS( $\pi)$ ), Based on Income Percentile for Incomes of Business Owners, 2004-2005 and 2009-2010

\begin{tabular}{|c|c|c|c|c|}
\hline Variables & (1) & (2) & (3) & (4) \\
\hline POST & $\begin{array}{c}-3.431^{* * *} \\
(0.175)\end{array}$ & $\begin{array}{l}-3.909^{* * *} \\
(0.285)\end{array}$ & $\begin{array}{l}-1.075^{* * *} \\
(0.032)\end{array}$ & $\begin{array}{l}-1.602^{* * *} \\
(0.229)\end{array}$ \\
\hline Income percentile $(I P) \times P O S T$ & $\begin{array}{l}2.395^{* * *} \\
(0.178)\end{array}$ & $\begin{array}{l}2.351^{* * *} \\
(0.178)\end{array}$ & & \\
\hline $\begin{array}{l}\text { Income percentile (IP) } 0-10 \% \times \\
\text { POST }\end{array}$ & & & $\begin{array}{l}-1.803^{* * *} \\
(0.483)\end{array}$ & $\begin{array}{l}-1.775^{* * *} \\
(0.485)\end{array}$ \\
\hline $\begin{array}{l}\text { Income percentile (IP) } 10-20 \% \\
\times \text { POST }\end{array}$ & & & $\begin{array}{l}-1.315^{* * *} \\
(0.357)\end{array}$ & $\begin{array}{l}-1.342^{* * *} \\
(0.358)\end{array}$ \\
\hline $\begin{array}{l}\text { Income percentile (IP) } 20-30 \% \\
\times \text { POST }\end{array}$ & & & $\begin{array}{l}-1.399^{* * *} \\
(0.342)\end{array}$ & $\begin{array}{c}-1.379^{* * *} \\
(0.336)\end{array}$ \\
\hline $\begin{array}{l}\text { Income percentile (IP) } 30-40 \% \\
\times \text { POST }\end{array}$ & & & $\begin{array}{l}-1.258^{* * *} \\
(0.277)\end{array}$ & $\begin{array}{l}-1.237^{* * *} \\
(0.278)\end{array}$ \\
\hline $\begin{array}{l}\text { Income percentile (IP) } 40-50 \% \\
\times \text { POST }\end{array}$ & & & $\begin{array}{c}-1.535^{* * *} \\
(0.240)\end{array}$ & $\begin{array}{l}-1.526^{* * *} \\
(0.234)\end{array}$ \\
\hline $\begin{array}{l}\text { Income percentile (IP) } 50-60 \% \\
\times P O S T\end{array}$ & & & $\begin{array}{l}-0.859^{* * *} \\
(0.200)\end{array}$ & $\begin{array}{l}-0.833^{* * *} \\
(0.200)\end{array}$ \\
\hline $\begin{array}{l}\text { Income percentile (IP) 60-70\% } \\
\times \text { POST }\end{array}$ & & & $\begin{array}{l}-0.889^{* * *} \\
(0.127)\end{array}$ & $\begin{array}{l}-0.865^{* * *} \\
(0.127)\end{array}$ \\
\hline $\begin{array}{l}\text { Income percentile (IP) 70-80\% } \\
\times \text { POST }\end{array}$ & & & $\begin{array}{l}-0.723^{* * *} \\
(0.086)\end{array}$ & $\begin{array}{l}-0.695^{* * *} \\
(0.085)\end{array}$ \\
\hline $\begin{array}{l}\text { Income percentile (IP) 80-90\% } \\
\times \text { POST }\end{array}$ & & & $\begin{array}{c}-0.382^{* * *} \\
(0.057) \\
\end{array}$ & $\begin{array}{l}-0.369^{* * *} \\
(0.057)\end{array}$ \\
\hline Initial profit dummies & yes & yes & yes & yes \\
\hline Initial profit dummies $\times$ POST & yes & yes & yes & yes \\
\hline $\begin{array}{l}\text { Sector dummies and sector } \\
\text { dummies } \times \text { POST }\end{array}$ & no & yes & no & yes \\
\hline Firm fixed effects & yes & yes & yes & yes \\
\hline $\mathrm{R}^{2}$ & 0.724 & 0.725 & 0.724 & 0.725 \\
\hline $\mathrm{N}$ & 155,647 & 155,647 & 155,647 & 155,647 \\
\hline
\end{tabular}

Notes: Dependent variable is $I H S(\pi)$ per firm in each year. Levels of significance: $10 \%{ }^{*}, 5 \%{ }^{* *}, 1 \%{ }^{* * *}$.

Standard errors are clustered at the firm level. (Clustering at the owner level is complicated because there can be multiple and overlapping owners.) IP is measured on a 0-1 scale in the regressions. The main effect of IP is absorbed by the firm fixed effects. In columns (3) and (4), the IP decile $\times$ POST interactions are relative to the top decile. 
Table 8: Income Percentiles of Business Owners and Workers, Individual and Family, by FMW, 2005

\begin{tabular}{|c|c|c|c|c|}
\hline & $(1)$ & $(2)$ & $(3)$ & $(4)$ \\
\hline $\boldsymbol{F M} \boldsymbol{W}$ & $\begin{array}{c}\text { Business owners' } \\
\text { income percentile }\end{array}$ & $\begin{array}{c}\text { Workers’ income } \\
\text { percentile }\end{array}$ & $\begin{array}{c}\text { Business owners' family } \\
\text { income percentile }\end{array}$ & $\begin{array}{c}\text { Workers' family } \\
\text { income percentile }\end{array}$ \\
\hline 0 & 88 & 77 & 71 & 57 \\
\hline$<10 \%$ & 94 & 77 & 82 & 57 \\
\hline $10-20 \%$ & 87 & 60 & 72 & 44 \\
\hline $20-30 \%$ & 85 & 54 & 69 & 37 \\
\hline $30-40 \%$ & 81 & 48 & 63 & 35 \\
\hline $40-50 \%$ & 79 & 44 & 61 & 31 \\
\hline $50-60 \%$ & 80 & 38 & 56 & 30 \\
\hline $60-70 \%$ & 78 & 38 & 57 & 28 \\
\hline $70-80 \%$ & 78 & 38 & 53 & 24 \\
\hline $80-90 \%$ & 79 & 34 & 48 & 49 \\
\hline $90-100 \%$ & 74 & 36 & 68 & \\
\hline Total & 87 & 68 & & 25 \\
\hline
\end{tabular}

Note: Individual figures represent approximate rank of column (5) in Tables 9 and 10. Family income figures represent approximate rank of column (10) in Table 9. Family income represents combined income of both married spouses in 2005. Annual owner or worker earnings below 6,000 NIS were omitted from calculation, as these can reflect small components of income that are not labor income from the main job. The rank was calculated based on the family income distribution including both owners' and workers' families. 
Table 9: Descriptive Statistics for Family Income by FMW: Married Business Owners and Workers, 2005

\begin{tabular}{|c|c|c|c|c|c|c|c|c|c|c|c|c|}
\hline \multicolumn{13}{|c|}{ A. Owners } \\
\hline & (1) & (2) & (3) & (4) & (5) & (6) & (7) & (8) & (9) & (10) & (11) & (12) \\
\hline$F M W$ & $\mathrm{~N}$ & $\begin{array}{l}\text { Average } \\
\text { age }\end{array}$ & $\%$ female & $\begin{array}{c}\text { \# children } \\
\text { under } 18 \\
\text { in } 2005 \\
\end{array}$ & $\begin{array}{l}\text { Owners } \\
\text { income }\end{array}$ & $\begin{array}{c}\text { Spouse } \\
\text { age }\end{array}$ & $\begin{array}{l}\text { Spouse \% } \\
\text { female }\end{array}$ & $\begin{array}{l}\text { Annual } \\
\text { spouse } \\
\text { income }\end{array}$ & $\begin{array}{c}\text { \% of } \\
\text { spouses } \\
\text { working }\end{array}$ & $\begin{array}{l}\text { Family } \\
\text { income }\end{array}$ & $\begin{array}{l}\text { Family income } \\
\text { relative to } \\
\text { average in } \\
0<F M W \leq 0.1 \\
\text { range } \\
\end{array}$ & $\begin{array}{c}\text { Owner/ } \\
\text { spouse } \\
\text { income } \\
\text { ratio }\end{array}$ \\
\hline 0 & 28,904 & 49.85 & $4.4 \%$ & 2.33 & 235,192 & 46.9 & $95.7 \%$ & 116,235 & $64.3 \%$ & 312,083 & $68 \%$ & 3.1 \\
\hline$<10 \%$ & 3,419 & 52.66 & $2.7 \%$ & 2.32 & 372,911 & 49.4 & $97.3 \%$ & 140,150 & $59.4 \%$ & 458,600 & $100 \%$ & 4.5 \\
\hline $10-20 \%$ & 5,181 & 50.92 & $3.4 \%$ & 2.34 & 230,751 & 47.7 & $96.6 \%$ & 104,015 & $63.7 \%$ & 298,226 & $65 \%$ & 3.5 \\
\hline $20-30 \%$ & 3,086 & 49.50 & $4.5 \%$ & 2.38 & 202,910 & 46.4 & $95.5 \%$ & 101,814 & $66.1 \%$ & 269,795 & $59 \%$ & 3.0 \\
\hline $30-40 \%$ & 3,712 & 49.05 & $4.4 \%$ & 2.44 & 168,659 & 45.8 & $95.7 \%$ & 91,188 & $66.9 \%$ & 229,877 & $50 \%$ & 2.8 \\
\hline $40-50 \%$ & 3,962 & 49.26 & $5.1 \%$ & 2.38 & 159,372 & 46.1 & $95.0 \%$ & 88,750 & $67.4 \%$ & 221,902 & $48 \%$ & 2.7 \\
\hline $50-60 \%$ & 801 & 48.37 & $4.4 \%$ & 2.45 & 166,414 & 45.0 & $95.7 \%$ & 86,703 & $63.8 \%$ & 223,853 & $49 \%$ & 3.0 \\
\hline $60-70 \%$ & 1,149 & 48.63 & $5.0 \%$ & 2.48 & 159,633 & 45.2 & $95.1 \%$ & 82,982 & $64.2 \%$ & 215,152 & $47 \%$ & 3.0 \\
\hline $70-80 \%$ & 628 & 47.16 & $6.2 \%$ & 2.64 & 149,760 & 44.1 & $93.9 \%$ & 87,533 & $64.3 \%$ & 206,732 & $45 \%$ & 2.7 \\
\hline $80-90 \%$ & 258 & 45.96 & $5.8 \%$ & 2.63 & 168,803 & 42.3 & $94.1 \%$ & 92,481 & $53.9 \%$ & 217,249 & $47 \%$ & 3.4 \\
\hline $90-100 \%$ & 2,728 & 50.83 & $6.0 \%$ & 2.42 & 134,650 & 47.7 & $94.2 \%$ & 91,137 & $62.0 \%$ & 198,334 & $43 \%$ & 2.4 \\
\hline \multicolumn{13}{|c|}{ B. Workers } \\
\hline$F M W$ & $\mathrm{~N}$ & $\begin{array}{l}\text { Average } \\
\text { age }\end{array}$ & $\%$ female & $\begin{array}{l}\text { \# children } \\
\text { under } 18 \\
\text { in } 2005\end{array}$ & $\begin{array}{c}\text { Annual } \\
\text { earnings }\end{array}$ & $\begin{array}{c}\text { Spouse } \\
\text { age }\end{array}$ & $\begin{array}{l}\text { Spouse \% } \\
\text { female }\end{array}$ & $\begin{array}{l}\text { Annual } \\
\text { spouse } \\
\text { income }\end{array}$ & $\begin{array}{c}\text { \% of } \\
\text { spouses } \\
\text { working }\end{array}$ & $\begin{array}{l}\text { Family } \\
\text { income }\end{array}$ & $\begin{array}{c}\text { Family income } \\
\text { relative to } \\
0<F M W \leq 0.1 \\
\text { range }\end{array}$ & $\begin{array}{l}\text { Worker/ } \\
\text { spouse } \\
\text { income } \\
\text { ratio }\end{array}$ \\
\hline 0 & 228,395 & 40.72 & $29.3 \%$ & 1.44 & 131,069 & 39.1 & $66.1 \%$ & 104,518 & $67.4 \%$ & 207,498 & $102 \%$ & 1.9 \\
\hline$<10 \%$ & 263,140 & 40.06 & $34.5 \%$ & 1.35 & 130,888 & 38.6 & $61.6 \%$ & 98,712 & $70.8 \%$ & 202,744 & $100 \%$ & 1.9 \\
\hline $10-20 \%$ & 100,238 & 40.04 & $45.7 \%$ & 1.35 & 73,505 & 39.4 & $47.5 \%$ & 89,811 & $65.1 \%$ & 138,431 & $68 \%$ & 1.3 \\
\hline $20-30 \%$ & 60,511 & 38.54 & $46.5 \%$ & 1.26 & 62,541 & 37.9 & $47.0 \%$ & 85,500 & $65.1 \%$ & 122,979 & $61 \%$ & 1.1 \\
\hline $30-40 \%$ & 60,808 & 38.47 & $50.1 \%$ & 1.22 & 53,218 & 38.0 & $42.6 \%$ & 81,848 & $64.6 \%$ & 112,959 & $56 \%$ & 1.0 \\
\hline $40-50 \%$ & 37,324 & 38.42 & $48.7 \%$ & 1.27 & 49,519 & 38.2 & $43.6 \%$ & 83,757 & $63.0 \%$ & 107,895 & $53 \%$ & 0.9 \\
\hline $50-60 \%$ & 19,391 & 38.35 & $52.4 \%$ & 1.22 & 41,239 & 38.3 & $39.4 \%$ & 74,144 & $62.3 \%$ & 93,238 & $46 \%$ & 0.9 \\
\hline $60-70 \%$ & 23,041 & 39.63 & $59.0 \%$ & 1.26 & 38,086 & 39.9 & $33.6 \%$ & 74,344 & $63.7 \%$ & 89,567 & $44 \%$ & 0.8 \\
\hline $70-80 \%$ & 10,339 & 38.18 & $55.0 \%$ & 1.32 & 37,129 & 38.4 & $34.8 \%$ & 73,247 & $60.2 \%$ & 85,074 & $42 \%$ & 0.8 \\
\hline $80-90 \%$ & 9,759 & 40.66 & $66.7 \%$ & 1.40 & 29,494 & 41.2 & $24.1 \%$ & 71,446 & $59.8 \%$ & 74,276 & $37 \%$ & 0.7 \\
\hline $90-100 \%$ & 18,561 & 43.81 & $70.1 \%$ & 1.32 & 28,652 & 44.1 & $21.9 \%$ & 79,643 & $58.7 \%$ & 74,137 & $37 \%$ & 0.6 \\
\hline
\end{tabular}

Notes: Annual owner or worker earnings below 6,000 NIS were omitted from calculation. Family income is calculated by combining spouses' incomes. 
Table 10: Descriptive Statistics by FMW: Single Business Owners and Workers, 2005

\begin{tabular}{|c|c|c|c|c|c|}
\hline \multicolumn{6}{|c|}{ A. Owners } \\
\hline & (1) & (2) & (3) & (4) & (5) \\
\hline$F M W$ & $\mathrm{~N}$ & Age & $\%$ female & $\begin{array}{l}\text { \# children under } \\
18 \text { in } 2005\end{array}$ & $\begin{array}{l}\text { Annual owner } \\
\text { earnings }\end{array}$ \\
\hline 0 & 5,347 & 47.38 & $21.5 \%$ & 1.80 & 191,728 \\
\hline$<10 \%$ & 491 & 53.35 & $25.7 \%$ & 1.79 & 393,442 \\
\hline $10-20 \%$ & 766 & 49.20 & $23.5 \%$ & 1.82 & 199,852 \\
\hline $20-30 \%$ & 489 & 46.60 & $26.6 \%$ & 1.89 & 160,847 \\
\hline $30-40 \%$ & 667 & 47.07 & $25.8 \%$ & 1.81 & 142,512 \\
\hline $40-50 \%$ & 773 & 45.72 & $25.5 \%$ & 1.86 & 124,418 \\
\hline $50-60 \%$ & 150 & 44.31 & $19.3 \%$ & 2.00 & 151,856 \\
\hline $60-70 \%$ & 236 & 43.35 & $23.7 \%$ & 1.79 & 105,619 \\
\hline $70-80 \%$ & 123 & 43.11 & $28.5 \%$ & 2.21 & 113,148 \\
\hline $80-90 \%$ & 62 & 39.81 & $16.1 \%$ & 2.58 & 108,605 \\
\hline $90-100 \%$ & 742 & 45.48 & $24.4 \%$ & 1.76 & 81,367 \\
\hline \multicolumn{6}{|c|}{ B. Workers } \\
\hline$F M W$ & $\mathrm{~N}$ & Age & $\%$ female & $\begin{array}{l}\text { \# children under } \\
18 \text { in } 2005\end{array}$ & Annual earnings \\
\hline 0 & 100,316 & 32.26 & $37.5 \%$ & 0.36 & 72,937 \\
\hline$<10 \%$ & 111,393 & 32.37 & $44.3 \%$ & 0.33 & 75,927 \\
\hline $10-20 \%$ & 62,031 & 31.12 & $47.8 \%$ & 0.31 & 43,042 \\
\hline $20-30 \%$ & 48,414 & 28.90 & $44.9 \%$ & 0.23 & 37,045 \\
\hline $30-40 \%$ & 52,701 & 28.09 & $47.6 \%$ & 0.22 & 30,853 \\
\hline $40-50 \%$ & 35,770 & 27.51 & $46.6 \%$ & 0.20 & 27,958 \\
\hline $50-60 \%$ & 21,264 & 27.11 & $47.5 \%$ & 0.21 & 24,578 \\
\hline $60-70 \%$ & 22,865 & 28.37 & $55.2 \%$ & 0.24 & 23,465 \\
\hline $70-80 \%$ & 10,429 & 27.75 & $49.9 \%$ & 0.22 & 23,289 \\
\hline $80-90 \%$ & 8,215 & 31.61 & $60.4 \%$ & 0.33 & 20,296 \\
\hline $90-100 \%$ & 12,312 & 38.46 & $71.6 \%$ & 0.44 & 21,396 \\
\hline
\end{tabular}

Notes: Annual owner or worker earnings below 6,000 NIS were omitted from calculation. 


\section{Online Appendix}

Figure A1: Google Trends Data on Minimum Wages

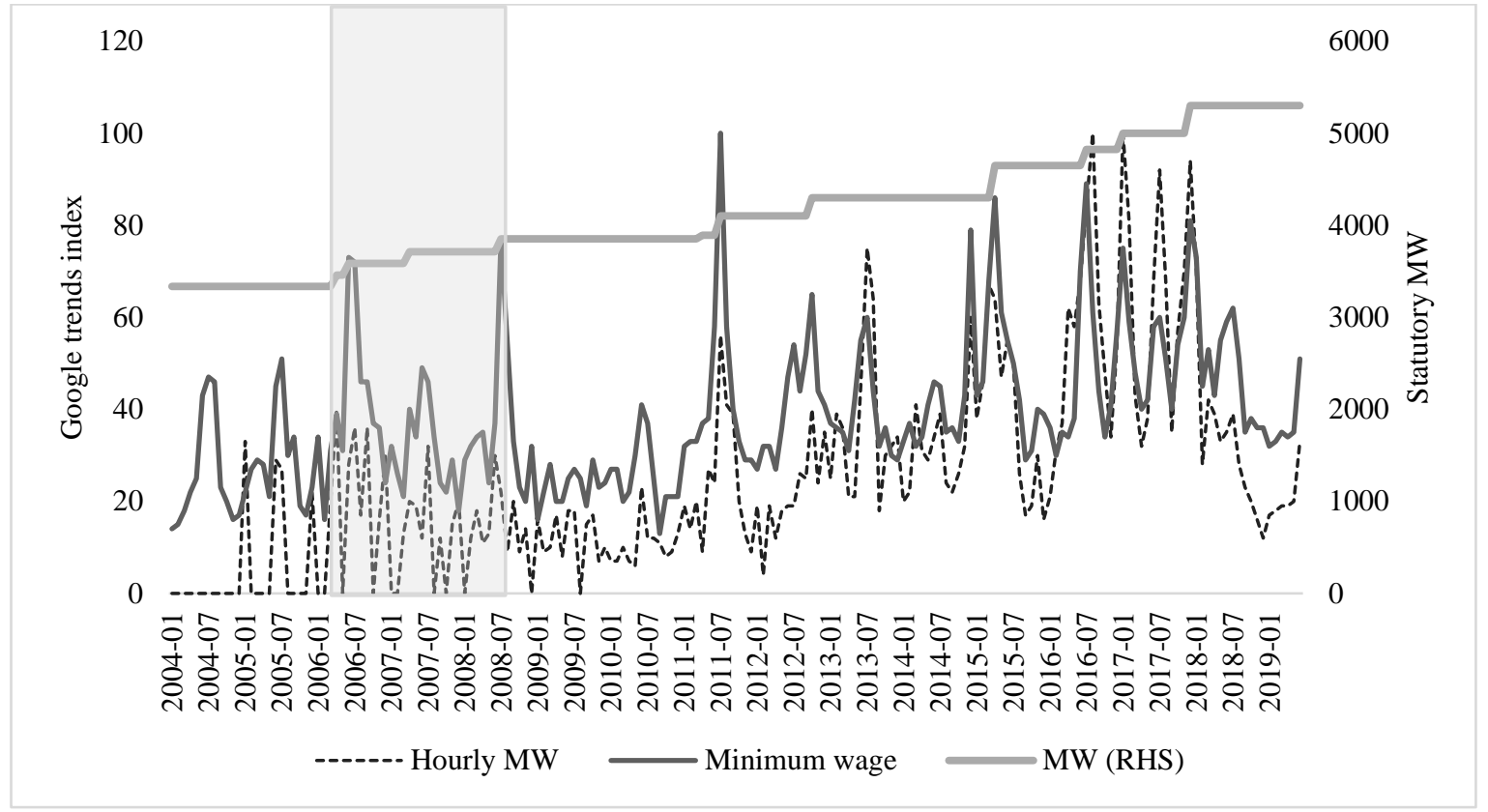

Notes: Leading search terms related to minimum wage in Hebrew as follows: minimum wage - שכר מינימום, hourly minimum wage - שכר מינימום לשעה. Google trends index is available since 2004. Zero values in Google trends commonly represent a search query sample that is not large enough to be reported. The shaded area shows the period of the minimum wage increases covered by our analysis.

Figure A2: Comparisons of Monthly Earnings of Employees in Companies and Unincorporated Businesses

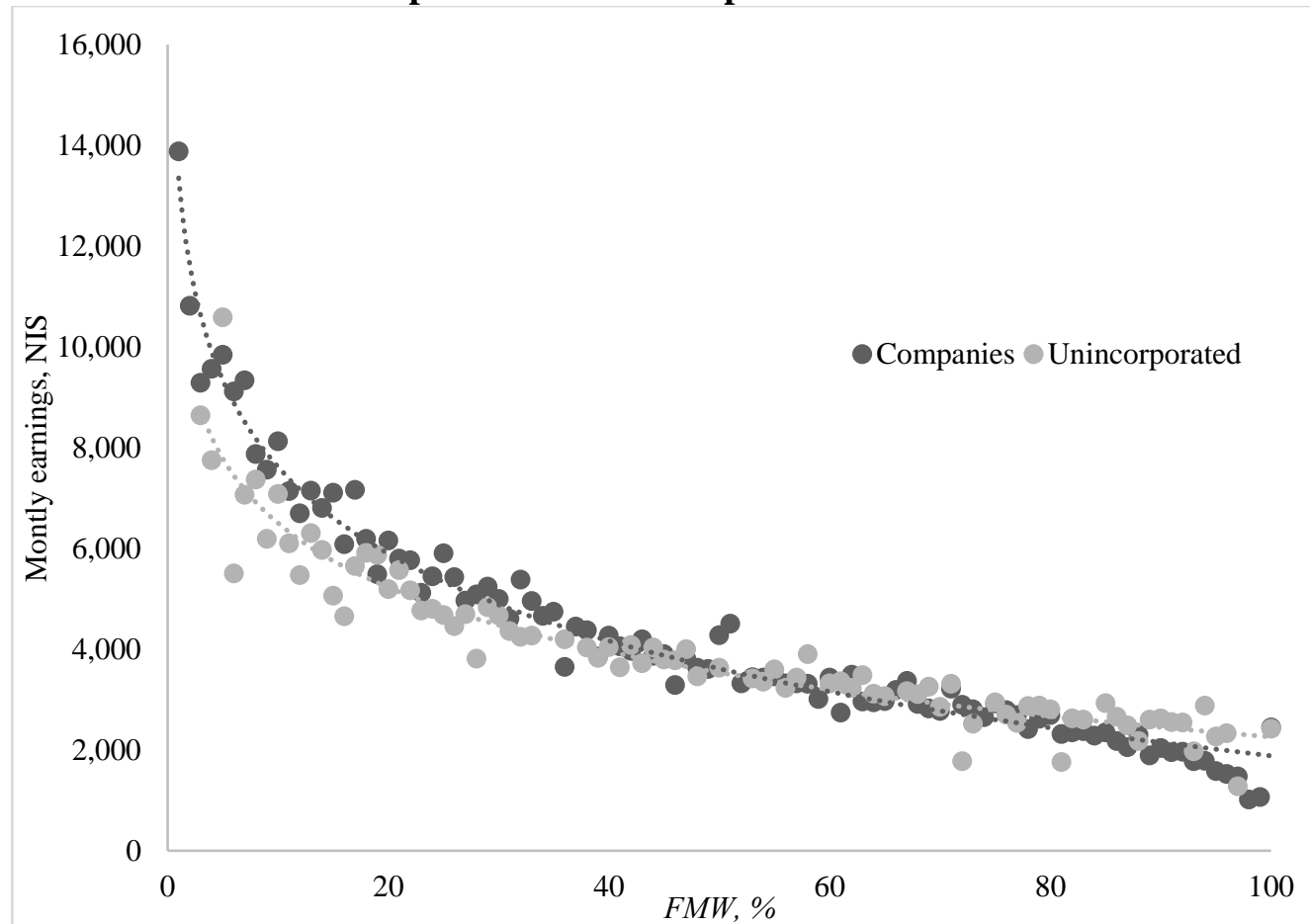

Note: Averages for $1 \%$ bins of FMW distribution in the year 2005. The chart uses the FMW distribution of unincorporated business that was calculated based on earnings of salaried workers employed by unincorporated business. 
Figure A3: Average Monthly Earnings by Sector, Tax Data and Income Survey, 2005

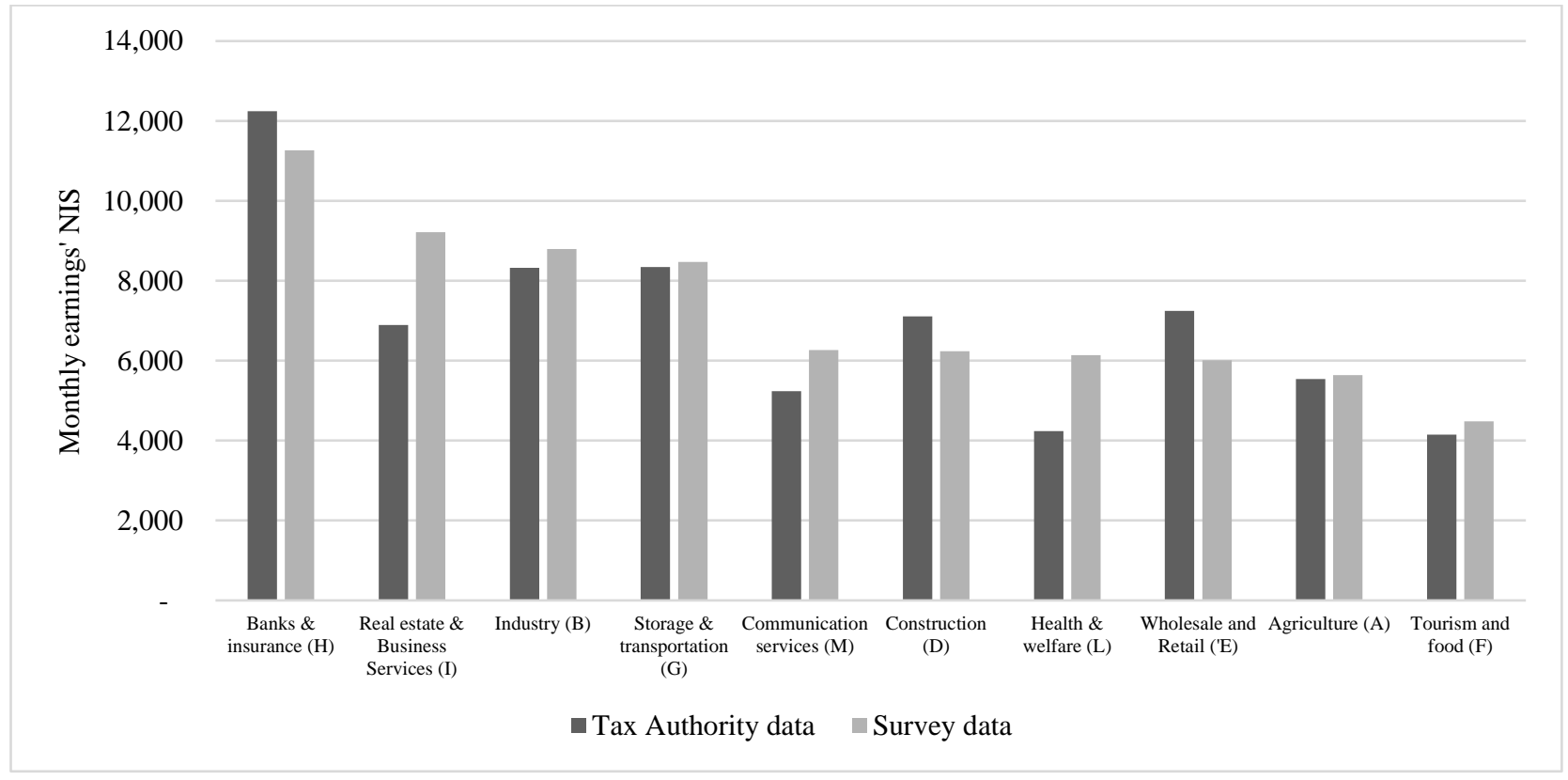

Figure A4: FMW by Sector, Tax Data and CBS Income Survey, 2005

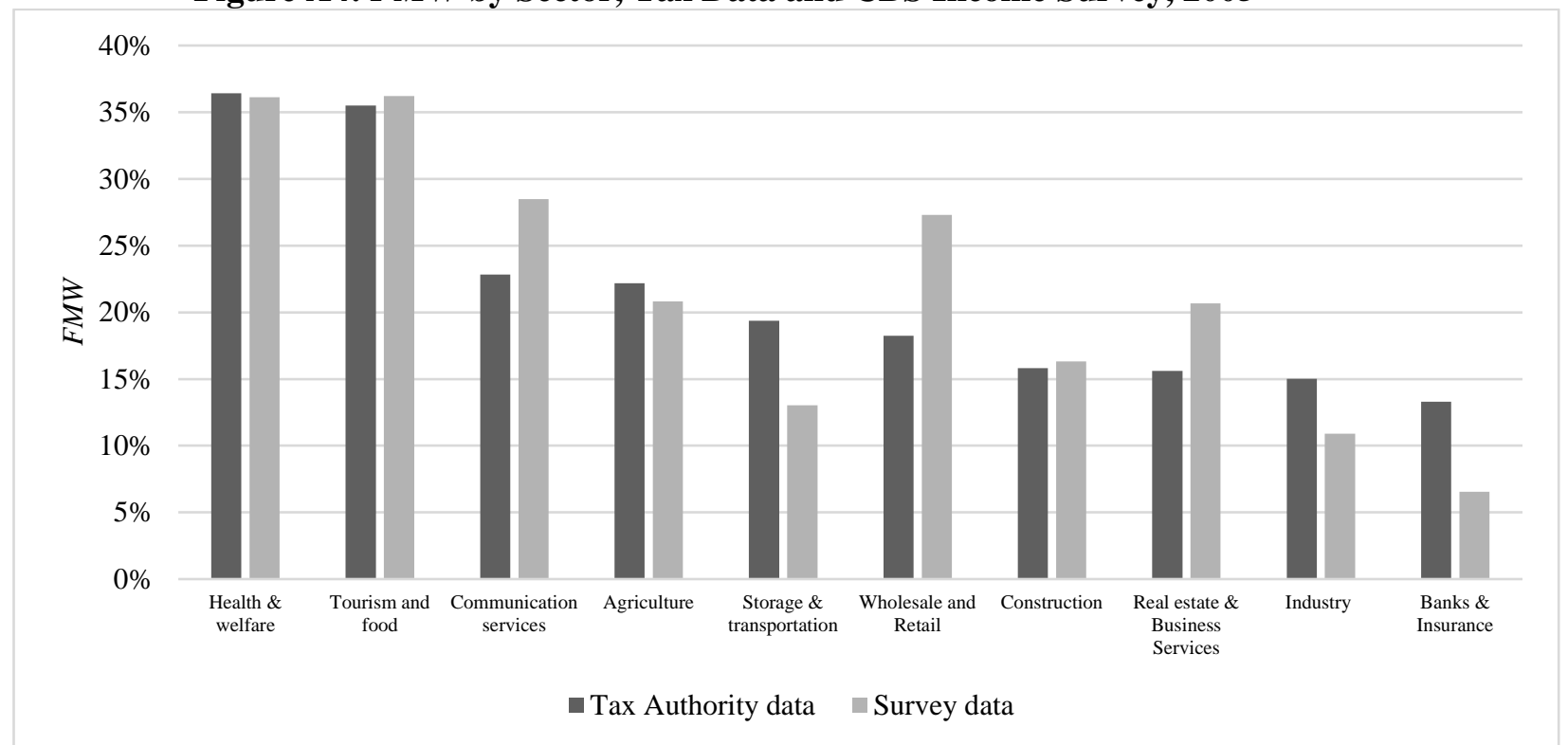

Note: The Central Bureau of Statistics (CBS) income survey includes earnings data. 
Figure A5: Distribution of Company-Year Observations in the Analysis Sample, by FMW Bins

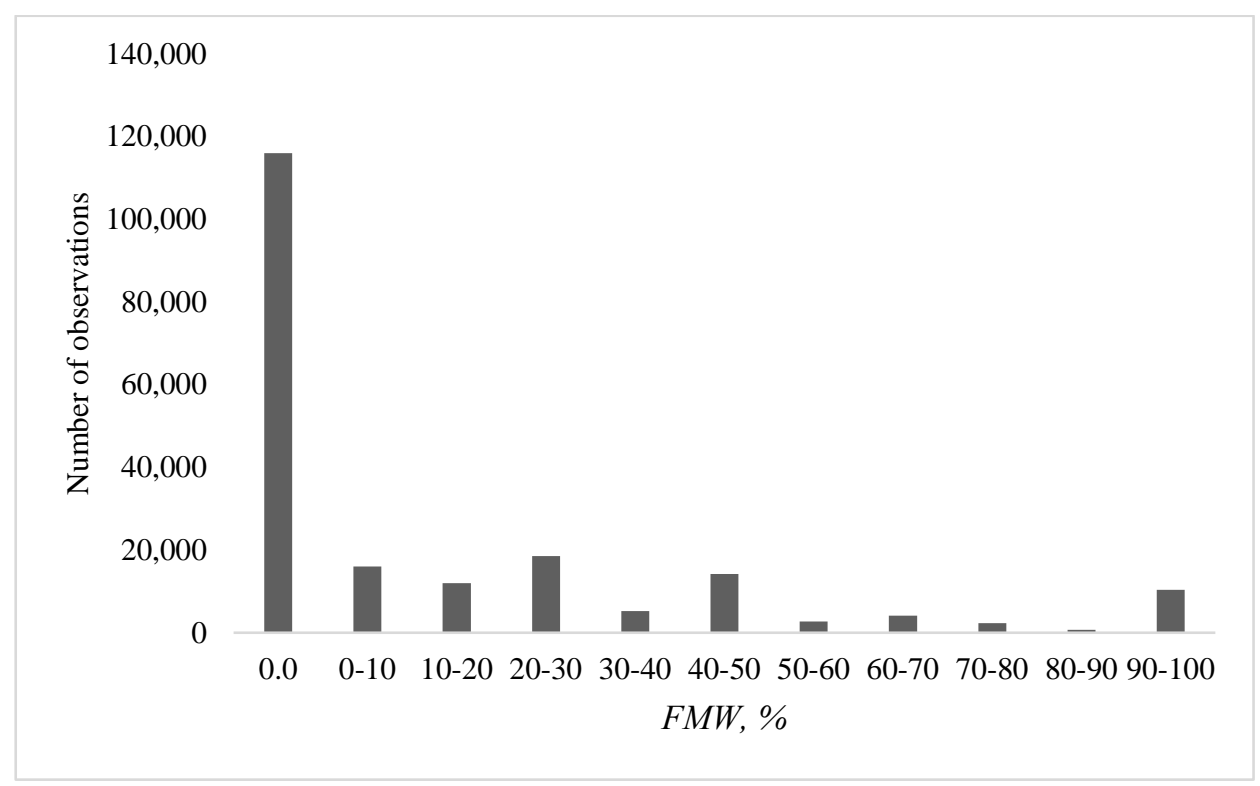


Figure A6: Analysis of Pre-trends
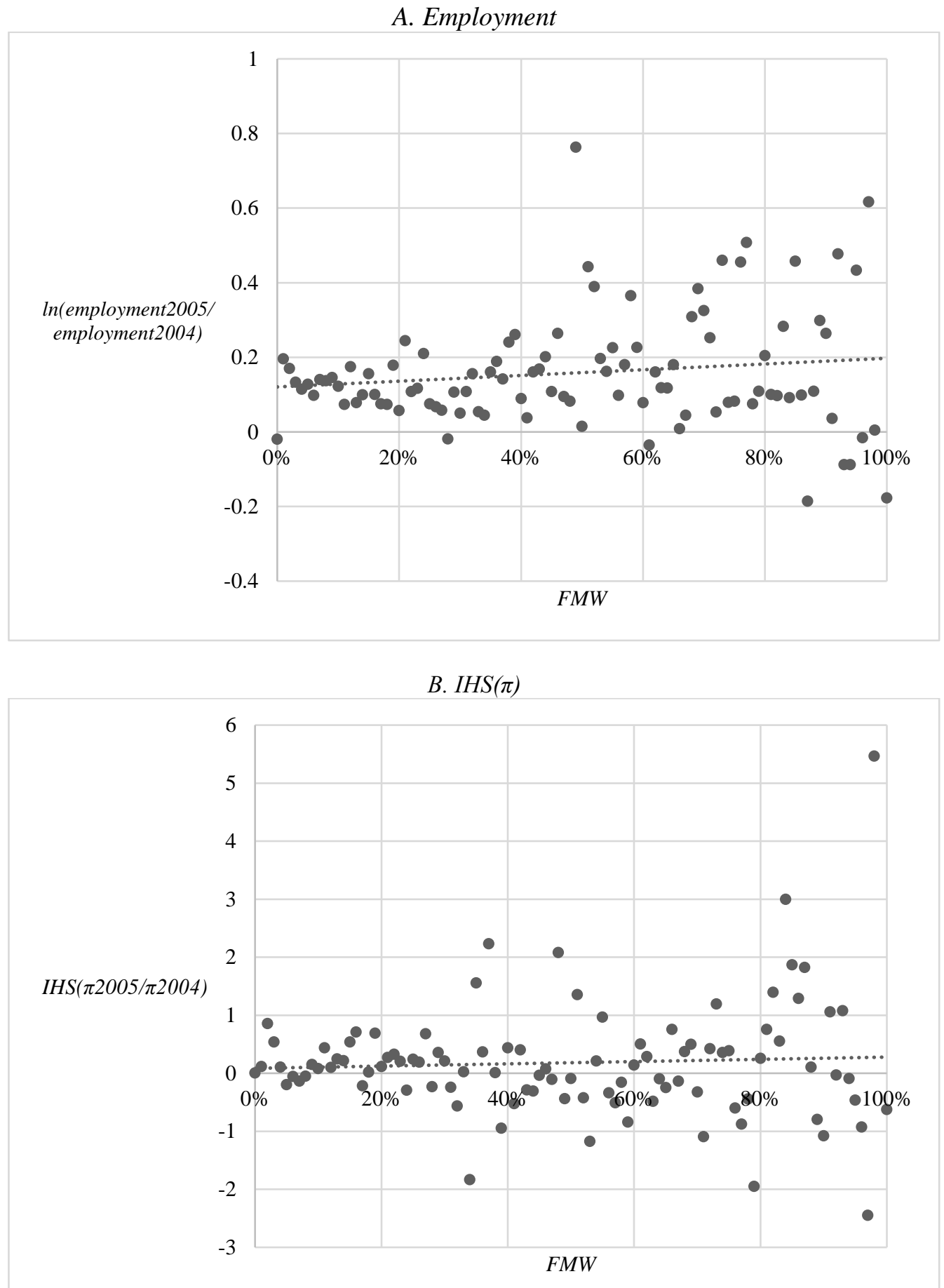

Note: For employment, in a regression of the pre-treatment employment change on $F M W$, the estimated coefficient (standard error) was $0.126(0.031)$. For $I H S(\pi)$, the estimate (standard error) was $0.088(0.200)$. 
Figure A7: Distribution of Firms by FMW Bins in 2005 and 2010

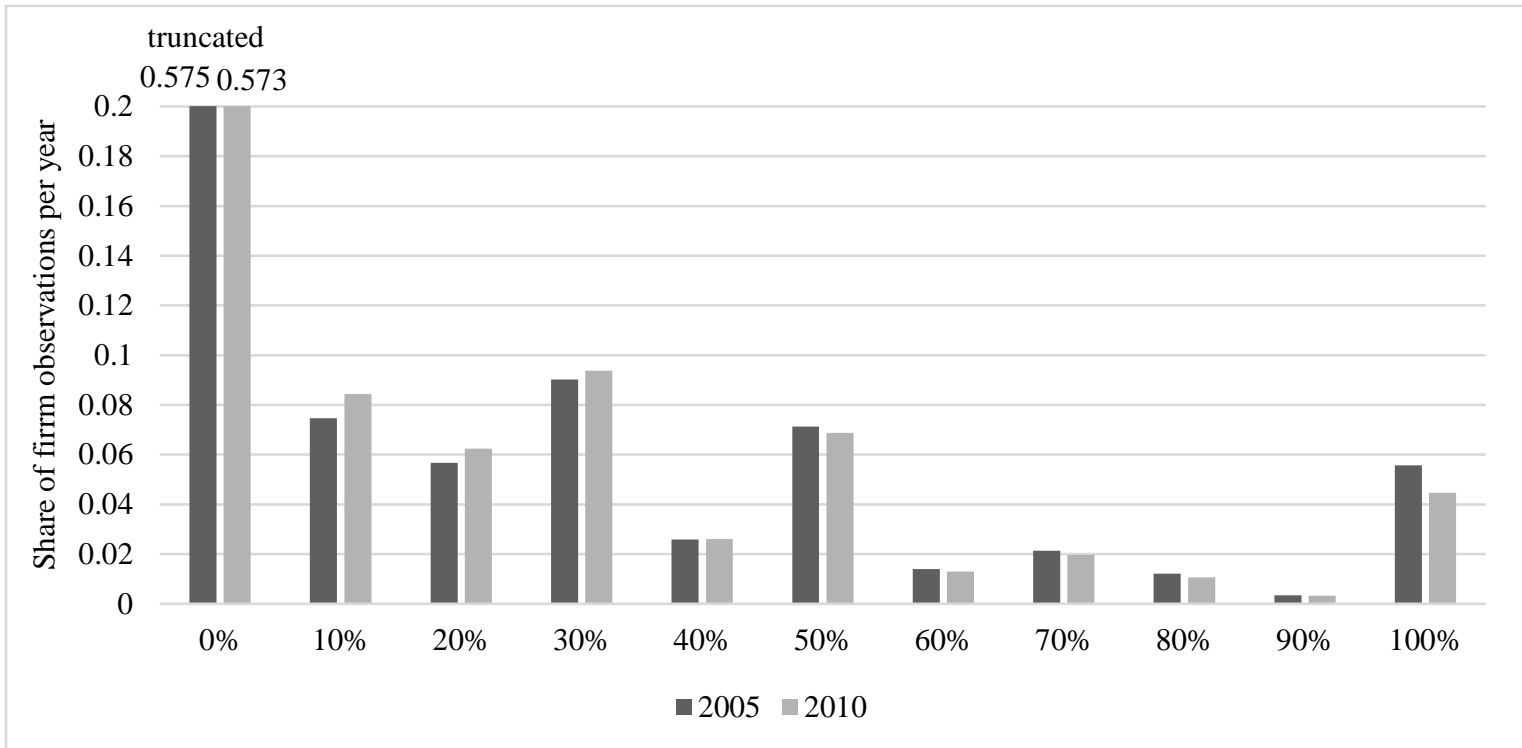

Notes: For the $F M W=0$ bin, we truncated the bars. The actual values are shown. Note that the $0 \%$ and $100 \%$ values refer to $F M W=0 \%$ or $100 \%$ exactly, while the other bars are for ranges (e.g., $10 \%$ for > $0 \%$ and $\leq 10 \%)$.

Figure A8: Distribution of Company-Year Observations on Publicly-Traded Companies, According to FMW Bins (Parallels Figure A5)

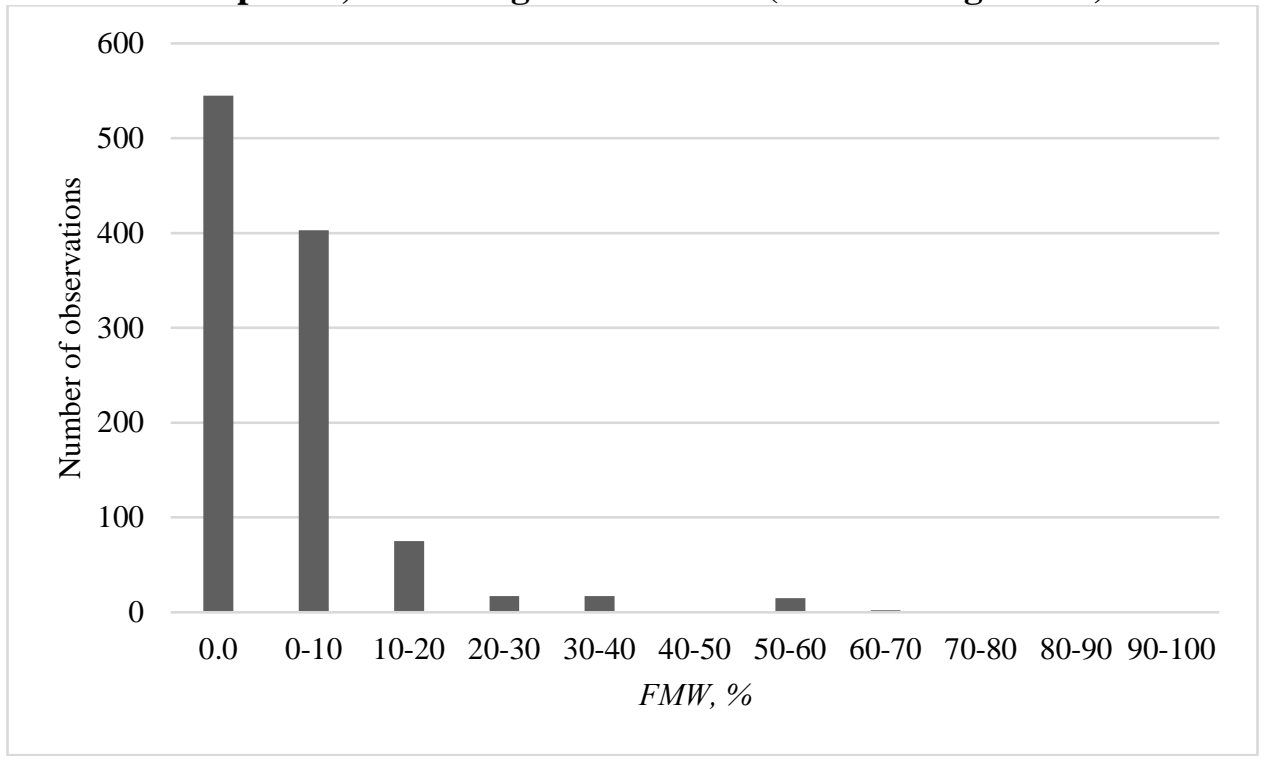

Note: This figure covers publicly-traded companies. 
Table A1: Construction of Analysis Sample, and Descriptive Statistics

\begin{tabular}{|l|c|c|c|c|c|}
\hline & $\begin{array}{c}\text { Number of } \\
\text { company } \\
\text { observations }\end{array}$ & $\begin{array}{c}\text { Number of } \\
\text { employee } \\
\text { observations on } \\
\text { the main job }\end{array}$ & $\begin{array}{c}\text { Employees per company } \\
\text { (min, median, mean, max) }\end{array}$ & $\begin{array}{c}\text { PMW } \\
\text { Profit rate } \\
\text { (min, median, mean, max) }\end{array}$ & $\begin{array}{c}(-35,331,478,0.08,-1,667.6,9,892,492) \\
\text { (min, median, mean, max) }\end{array}$ \\
\hline $\begin{array}{l}\text { Full sample of companies } \\
\text { matched to employees, } \\
\text { 2004-2010 }\end{array}$ & 658,804 & $21,719,245$ & $(1,6,33.48,36,387)$ & $0.00,0.20,1.00)$ \\
\hline Exclude government sector & 654,159 & $19,668,656$ & $(1,6,30.54,32,606)$ & $(-35,331,478,0.08,-1,676.2,9,892,492)$ & $(0.00,0.00,0.20,1.00)$ \\
\hline Exclude non-profits & 593,865 & $17,185,309$ & $(1,6,29.35,32,606)$ & $(-35,331,478,0.09,-1,778.3,9,892,492)$ & $(0.00,0.00,0.18,1.00)$ \\
\hline $\begin{array}{l}\text { Exclude companies in } \\
\text { liquidation }\end{array}$ & 588,484 & $17,128,975$ & $(1,6,29.51,32,606)$ & $(-35,331,478,0.09,-1,793.8,9,892,492)$ & $(0.00,0.00,0.18,1.00)$ \\
\hline $\begin{array}{l}\text { Exclude companies likely to be } \\
\text { holding companies based on } \\
\text { extreme profit rate measures }\end{array}$ & 542,583 & $16,358,953$ & $(1,7,30.53,32,606)$ & $(-1,0.09,0.15,1)$ \\
\hline $\begin{array}{l}\text { Exclude companies established } \\
\text { after 2005 }\end{array}$ & 519,050 & $16,018,885$ & $(1,7,31.17,32,606)$ & $(-1,0.09,0.16,1)$ \\
\hline $\begin{array}{l}\text { Exclude companies with no } \\
\text { earnings data in 2005 }\end{array}$ & 356,893 & $13,120,034$ & $(1,8,36.85,32,606)$ & $(-1,0.10,0.16,1)$ \\
\hline $\begin{array}{l}\text { Exclude company observations } \\
\text { in 2006-2008 (treatment period) }\end{array}$ & 202,187 & $7,255,846$ & $(1,8,35.97,29,694)$ & $(0.00,0.18,1.00)$ \\
\hline
\end{tabular}

Note: Pre-treatment years are 2004-2005 and post-treatment years are 2009-2010. 
Table A2: Regression Estimates for Minimum Wage Effect on Log Employment, Based on Fraction Affected by Minimum Wage (FMW), 2004-2005 and 2009-2010, Excluding Financial Sector and Export-Oriented Companies

\begin{tabular}{|l|c|}
\hline Variables & $(1)$ \\
\hline POST & -0.058 \\
& $(0.049)$ \\
\hline FMW $\times$ POST & $-0.108^{* * *}$ \\
& $(0.014)$ \\
\hline Sector dummies and sector dummies $\times$ POST & yes \\
\hline Firm fixed effects & yes \\
\hline $\mathrm{R}^{2}$ & 0.924 \\
\hline $\mathrm{N}$ & 192,825 \\
\hline
\end{tabular}

Notes: See notes to Table 2 in the paper. The specification corresponds to column (3) of Table 2 in the paper. The main effect of $F M W$ is absorbed by the firm fixed effects.

Table A3: Regression Estimates for Minimum Wage Effect on Log Employment, with Separate FMW Bins, 2004-2005 and 2009-2010, Excluding Financial Sector and Export-Oriented Companies

\begin{tabular}{|c|c|c|c|}
\hline Variables & (1) & (2) & (3) \\
\hline POST & $\begin{array}{l}0.026^{* * *} \\
(0.005)\end{array}$ & $\begin{array}{c}-0.036 \\
(0.049) \\
\end{array}$ & $\begin{array}{l}-0.035 \\
(0.049)\end{array}$ \\
\hline$F M W>0-20 \% \times P O S T$ & $\begin{array}{c}-0.073^{* * *} \\
(0.009)\end{array}$ & $\begin{array}{c}-0.073^{* * *} \\
(0.009)\end{array}$ & $\begin{array}{c}-0.073^{* * *} \\
(0.009)\end{array}$ \\
\hline FMW 20-40\% × POST & $\begin{array}{l}-0.133^{* * *} \\
(0.010)\end{array}$ & $\begin{array}{c}-0.130^{* * *} \\
(0.011)\end{array}$ & $\begin{array}{c}-0.130^{* * *} \\
(0.011)\end{array}$ \\
\hline FMW 40-60\% × POST & $\begin{array}{c}-0.127^{* * *} \\
(0.013)\end{array}$ & $\begin{array}{c}-0.123^{* * *} \\
(0.013)\end{array}$ & $\begin{array}{c}-0.124^{* * *} \\
(0.013)\end{array}$ \\
\hline FMW 60-80\% × POST & $\begin{array}{l}-0.182^{* * *} \\
(0.021)\end{array}$ & $\begin{array}{l}-0.176^{* * *} \\
(0.021)\end{array}$ & $\begin{array}{c}-0.176^{* * *} \\
(0.021)\end{array}$ \\
\hline FMW 80-100\% × POST & $\begin{array}{c}0.006 \\
(0.016)\end{array}$ & $\begin{array}{c}0.007 \\
(0.017)\end{array}$ & \\
\hline FMW 80-94\% × POST & & & $\begin{array}{l}-0.061^{*} \\
(0.037)\end{array}$ \\
\hline FMW 94-100\% × POST & & & $\begin{array}{c}0.015 \\
(0.018)\end{array}$ \\
\hline $\begin{array}{l}\text { Sector dummies and } \\
\text { sector dummies } \times P O S T\end{array}$ & no & yes & yes \\
\hline Firm fixed effects & yes & yes & yes \\
\hline $\mathrm{R}^{2}$ & 0.924 & 0.924 & 0.924 \\
\hline $\mathrm{N}$ & 192,825 & 192,825 & 192,825 \\
\hline
\end{tabular}

Notes: See notes to Table 4 in the paper. The specifications correspond to columns (1)-(3) of Table 4 in the paper. The main effects of the $F M W$ bins are absorbed by the firm fixed effects. The $F M W \times P O S T$ interactions are relative to $F M W 0 \%$. 
Table A4: Regression Estimates of Minimum Wage Effect on Profits (IHS( $\pi)$ ), Based on Fraction Affected by Minimum Wage (FMW), 2004-2005 and 2009-2010, Excluding Financial Sector and Export-Oriented

\section{Companies}

\begin{tabular}{|c|c|c|c|c|c|}
\hline Variables & (1) & (2) & (3) & (4) & (5) \\
\hline & Full sample & $\begin{array}{c}\text { Sample: low initial } \\
\text { profits }\end{array}$ & $\begin{array}{l}\text { Sample: medium } \\
\text { low initial profits }\end{array}$ & $\begin{array}{l}\text { Sample: medium } \\
\text { initial profits }\end{array}$ & $\begin{array}{l}\text { Sample: high } \\
\text { initial profits }\end{array}$ \\
\hline$P O S T$ & $\begin{array}{l}-1.990^{* * *} \\
(0.227)\end{array}$ & $\begin{array}{l}4.589^{* * *} \\
(0.503)\end{array}$ & $\begin{array}{l}-1.323^{* * *} \\
(0.354)\end{array}$ & $\begin{array}{c}-1.669^{* * *} \\
(0.387)\end{array}$ & $\begin{array}{c}-1.835^{* * *} \\
(0.571)\end{array}$ \\
\hline$F M W \times P O S T$ & $\begin{array}{c}-0.715^{* * *} \\
(0.072) \\
\end{array}$ & $\begin{array}{c}-1.765^{* * *} \\
(0.155) \\
\end{array}$ & $\begin{array}{l}-0.185^{*} \\
(0.107) \\
\end{array}$ & $\begin{array}{c}-0.359^{* * *} \\
(0.125)\end{array}$ & $\begin{array}{c}-0.011 \\
(0.169) \\
\end{array}$ \\
\hline Initial profits dummies & yes & no & no & no & no \\
\hline Initial profits $\times P O S T$ & yes & no & no & no & no \\
\hline $\begin{array}{l}\text { Sector dummies and } \\
\text { sector dummies } \times \\
P O S T\end{array}$ & yes & yes & yes & yes & yes \\
\hline Firm fixed effects & yes & yes & yes & yes & yes \\
\hline $\mathrm{R}^{2}$ & 0.732 & 0.643 & 0.470 & 0.464 & 0.481 \\
\hline $\mathrm{N}$ & 193,237 & 45,124 & 46,355 & 50,365 & 51,393 \\
\hline
\end{tabular}

Notes: See notes to Table 5 in the paper. The specifications correspond to columns (3)-(7) of Table 5 in the paper. The main effect of $F M W$ is absorbed by the firm fixed effects.

Table A5: Regression Estimates of Minimum Wage Effect on Profits (IHS $(\pi)$ ), Based on Fraction Affected by Minimum Wage (FMW), with Separate FMW Bins, 2004-2005 and 2009-2010, Excluding Financial Sector and Export-Oriented Companies

\begin{tabular}{|l|c|c|}
\hline Variables & $(1)$ & $(2)$ \\
\hline POST & $-1.406^{* * *}$ & $-2.057^{* * *}$ \\
& $(0.038)$ & $(0.227)$ \\
\hline FMW $>0-20 \% \times$ POST & -0.001 & 0.078 \\
& $(0.060)$ & $(0.060)$ \\
\hline FMW 20-40\% × POST & -0.012 & 0.022 \\
& $(0.057)$ & $(0.057)$ \\
\hline FMW 40-60\% × POST & $-0.187^{* * *}$ & $-0.185^{* * *}$ \\
& $(0.065)$ & $(0.066)$ \\
\hline FMW 60-80\% $\times$ POST & $-0.438^{* * *}$ & $-0.454^{* * *}$ \\
& $(0.107)$ & $(0.108)$ \\
\hline FMW 80-100\% × POST & $-0.864^{* * *}$ & $-0.917^{* * *}$ \\
& $(0.086)$ & $(0.086)$ \\
\hline Initial profit dummies & yes & yes \\
\hline Initial profit dummies $\times$ POST & yes & yes \\
\hline Sector dummies and sector dummies $\times$ POST & no & yes \\
\hline Firm fixed effects & yes & yes \\
\hline $\mathrm{R}^{2}$ & 0.730 & 0.732 \\
\hline $\mathrm{N}$ & 193,237 & 193,237 \\
\hline
\end{tabular}

Notes: See notes to Table 6 in the paper. The specifications correspond to Table 6 in the paper. The main effects of the FMW bins are absorbed by the firm fixed effects. The $F M W$ $\times$ POST interactions are relative to FMW $0 \%$. 
Table A6: Regression Estimates of Minimum Wage Effect on Profits (IHS( $\pi)$ ), Based on Income Percentile for Incomes of Business Owners, 2004-2005 and 20092010, Excluding Financial Sector and Export-Oriented Companies

\begin{tabular}{|c|c|c|}
\hline Variables & (1) & (2) \\
\hline$P O S T$ & $\begin{array}{c}-3.419^{* * *} \\
(0.178)\end{array}$ & $\begin{array}{c}-3.891^{* * *} \\
(0.287)\end{array}$ \\
\hline Income percentile $(I P) \times P O S T$ & $\begin{array}{l}2.391^{* * *} \\
(0.181)\end{array}$ & $\begin{array}{c}2.348^{* * *} \\
(0.181)\end{array}$ \\
\hline Initial profit dummies & yes & yes \\
\hline Initial profit dummies $\times$ POST & yes & yes \\
\hline Sector dummies and sector dummies $\times P O S T$ & no & yes \\
\hline Firm fixed effects & yes & yes \\
\hline $\mathrm{R}^{2}$ & 0.723 & 0.724 \\
\hline $\mathrm{N}$ & 150,121 & 150,121 \\
\hline
\end{tabular}

Notes: See notes to Table 7 in the paper. The specifications correspond to columns (1) and (2) of Table 7 in the paper. The main effect of $I P$ is absorbed by the firm fixed effects. 
Table A7: Regression Estimates for Minimum Wage Effect on Log Earnings, Based on Fraction Affected by Minimum Wage (FMW), 2004-2005 and 2009-2010 (Parallels

Table 2)

\begin{tabular}{|l|c|c|c|}
\hline Variables & $(1)$ & $(2)$ & $(3)$ \\
\hline FMW & $-1.210^{* * *}$ & $-1.124^{* * *}$ & $\cdots$ \\
& $(0.007)$ & $(0.007)$ & $0.141^{* * *}$ \\
\hline POST & $0.142^{* * *}$ & $0.142^{* * *}$ & $(0.024)$ \\
& $(0.002)$ & $(0.025)$ & $0.208^{* * *}$ \\
\hline FMW $\times$ POST & $0.190^{* * *}$ & $0.188^{* * *}$ & $(0.008)$ \\
\hline Sector dummies and sector & $(0.009)$ & $(0.009)$ & yes \\
dummies $\times$ POST & no & yes & yes \\
\hline Firm fixed effects & no & no & 0.879 \\
\hline $\mathrm{R}^{2}$ & 0.279 & 0.338 & 201,742 \\
\hline $\mathrm{N}$ & 201,742 & 201,742 & 172 \\
\hline
\end{tabular}

Notes: See notes to Table 2. Dependent variable is average log(earnings) for workers in each firm and year. Three dots (...) indicates that the variable is absorbed by the firm fixed effects.

Table A8: Regression Estimates for Minimum Wage Effect on Log Earnings, with Separate FMW Bins, 2004-2005 and 2009-2010 Parallels Table 4

\begin{tabular}{|c|c|c|c|}
\hline Variables & (1) & (2) & (3) \\
\hline POST & $\begin{array}{l}0.117^{* * *} \\
(0.003)\end{array}$ & $\begin{array}{l}0.139^{* * *} \\
(0.024)\end{array}$ & $\begin{array}{l}0.140^{* * *} \\
(0.024)\end{array}$ \\
\hline$F M W>0-20 \% \times P O S T$ & $\begin{array}{l}0.045^{* * *} \\
(0.004)\end{array}$ & $\begin{array}{l}0.044^{* * *} \\
(0.004)\end{array}$ & $\begin{array}{l}0.044^{* * *} \\
(0.004)\end{array}$ \\
\hline FMW $20-40 \% \times$ POST & $\begin{array}{l}0.068^{* * *} \\
(0.005)\end{array}$ & $\begin{array}{l}0.070^{* * *} \\
(0.005)\end{array}$ & $\begin{array}{l}0.070^{* * *} \\
(0.005)\end{array}$ \\
\hline$F M W 40-60 \% \times P O S T$ & $\begin{array}{l}0.093^{* * *} \\
(0.006)\end{array}$ & $\begin{array}{l}0.095^{* * *} \\
(0.007)\end{array}$ & $\begin{array}{l}0.095^{* * *} \\
(0.007)\end{array}$ \\
\hline FMW 60-80\% × POST & $\begin{array}{l}0.125^{* * *} \\
(0.009)\end{array}$ & $\begin{array}{l}0.128^{* * *} \\
(0.009)\end{array}$ & $\begin{array}{l}0.128^{* * *} \\
(0.009)\end{array}$ \\
\hline FMW $80-100 \% \times$ POST & $\begin{array}{l}0.217^{* * *} \\
(0.012)\end{array}$ & $\begin{array}{l}0.220^{* * *} \\
(0.012)\end{array}$ & \\
\hline FMW 80-94\% × POST & & & $\begin{array}{l}0.123^{* * *} \\
(0.016)\end{array}$ \\
\hline FMW 94-100\% × POST & & & $\begin{array}{l}0.231^{* * *} \\
(0.013)\end{array}$ \\
\hline $\begin{array}{l}\text { Sector dummies and } \\
\text { sector dummies } \times P O S T\end{array}$ & no & yes & yes \\
\hline Firm fixed effects & yes & yes & yes \\
\hline $\mathrm{R}^{2}$ & 0.879 & 0.879 & 0.879 \\
\hline $\mathrm{N}$ & 201,742 & 201,742 & 201,742 \\
\hline
\end{tabular}

Notes: See notes to Table 4. Dependent variable is log(earnings) per firm in each year. 
Table A9: Regression Estimates of Minimum Wage Effect on Profits (IHS( $\pi)$ ), Based on Fraction Affected by Minimum Wage (FMW), 2004-2005 and 20092010, Alternative Treatment of Exiters

\begin{tabular}{|l|c|c|c|}
\hline Variables & $(1)$ & $(2)$ & $(3)$ \\
& $\begin{array}{c}\text { Dropping exiters } \\
\text { (Table 5, column (3)) }\end{array}$ & $\begin{array}{c}\text { Include } \\
\text { exiters, } \pi=0\end{array}$ & $\begin{array}{c}\text { Include exiters, } \pi=0, \\
\text { set negative } \pi \text { to 0 }\end{array}$ \\
\hline POST & $-2.017^{* * *}$ & $-1.612^{* * * *}$ & $-2.188^{* * *}$ \\
& $(0.227)$ & $(0.147)$ & $(0.195)$ \\
\hline$F M W \times$ POST & $-0.720^{* * *}$ & $-0.295^{* * *}$ & $-0.394^{* * *}$ \\
$(0.070)$ & $(0.043)$ & $(0.058)$ \\
\hline $\begin{array}{l}\text { Initial profits } \\
\text { dummies }\end{array}$ & yes & yes & yes \\
\hline Initial profits $\times$ POST & yes & yes & yes \\
\hline Sector dummies and & yes & yes & yes \\
sector dummies $\times$ & & & \\
$P O S T$ & & yes & yes \\
\hline Firm fixed effects & yes & 0.662 & 0.611 \\
\hline $\mathrm{R}^{2}$ & 0.732 & 225,313 & 225,313 \\
\hline $\mathrm{N}$ & 202,187 & & \\
\hline
\end{tabular}

Notes: Dependent variable is $I H S(\pi)$ per firm in each year, including zero values for profits after exit in the post period and correcting to zero if profits had negative values. Levels of significance: $10 \%^{*}, 5 \%^{* *}, 1 \%^{* * *}$. Standard errors are clustered at the firm level. $F M W$ is measured on a $0-1$ scale in the regressions. The main effect of $F M W$ is absorbed by the firm fixed effects. 
Table A10: Regression Estimates of Linear Probability Model for Survival to the Post-period (2009-2010), Based on Fraction Affected by Minimum Wage (FMW), with Separate FMW Bins

\begin{tabular}{|c|c|c|c|}
\hline Variables & $(1)$ & $(2)$ & (3) \\
\hline$F M W>0-20 \%$ & $\begin{array}{l}0.093^{* * *} \\
(0.005)\end{array}$ & $\begin{array}{l}0.074^{* * *} \\
(0.005)\end{array}$ & $\begin{array}{l}0.075^{* * *} \\
(0.005)\end{array}$ \\
\hline FMW 20-40\% & $\begin{array}{l}0.045^{* * *} \\
(0.005)\end{array}$ & $\begin{array}{l}0.047^{* * *} \\
(0.005)\end{array}$ & $\begin{array}{l}0.050^{* * *} \\
(0.005)\end{array}$ \\
\hline FMW 40-60\% & $\begin{array}{c}-0.014^{* * *} \\
(0.006)\end{array}$ & $\begin{array}{l}-0.005 \\
(0.006) \\
\end{array}$ & $\begin{array}{l}-0.011^{*} \\
(0.006)\end{array}$ \\
\hline FMW 60-80\% & $\begin{array}{c}-0.048^{* * *} \\
(0.009)\end{array}$ & $\begin{array}{l}-0.021^{* *} \\
(0.018)\end{array}$ & $\begin{array}{l}-0.013 \\
(0.009)\end{array}$ \\
\hline FMW 80-100\% & $\begin{array}{c}-0.123^{* * *} \\
(0.007)\end{array}$ & $\begin{array}{l}-0.076^{* * *} \\
(0.007)\end{array}$ & $\begin{array}{c}-0.076^{* * *} \\
(0.007)\end{array}$ \\
\hline Initial profits dummies: & no & yes & yes \\
\hline Low profits & & $\begin{array}{l}-0.173^{* * *} \\
(0.005)\end{array}$ & $\begin{array}{c}-0.172^{* * *} \\
(0.005)\end{array}$ \\
\hline Mid-Low profits & & $\begin{array}{l}-0.108^{* * *} \\
(0.005) \\
\end{array}$ & $\begin{array}{c}-0.105^{* * *} \\
(0.005) \\
\end{array}$ \\
\hline Mid profits & & $\begin{array}{l}-0.033^{* * *} \\
(0.005)\end{array}$ & $\begin{array}{c}-0.033^{* * *} \\
(0.004)\end{array}$ \\
\hline $\begin{array}{l}\text { Sector dummies and sector dummies } \times \\
\text { POST }\end{array}$ & no & no & yes \\
\hline $\mathrm{R}^{2}$ & 0.016 & 0.044 & 0.052 \\
\hline $\mathrm{N}$ & 57,520 & 57,520 & 57,520 \\
\hline
\end{tabular}

Notes: Dependent variable is a dummy variable for survival, set equal to 1 for companies that appear in the post-period (2009-2010) and 0 otherwise. OLS regression with one observation per firm. Levels of significance: $10 \%{ }^{*}, 5 \%^{* *}, 1 \%{ }^{* * *}$. Effects of $F M W$ bins are estimated relative to $F M W 0 \%$. Estimated effects of the profit quartile dummy variables are estimated relative to "high." 
Table A11: Regression Estimates for Minimum Wage Effect on Log Employment, Based on Fraction Affected by Minimum Wage (FMW), 2004 only and 2009-2010, Parallels

Table 2, column (3)

\begin{tabular}{|l|c|}
\hline Variables & $(3)$ \\
\hline POST & -0.054 \\
& $(0.036)$ \\
\hline FMW $\times$ POST & $-0.131^{* * *}$ \\
& $(0.011)$ \\
\hline Sector dummies and sector dummies $\times$ POST & yes \\
\hline Firm fixed effects & yes \\
\hline $\mathrm{R}^{2}$ & 0.932 \\
\hline $\mathrm{N}$ & 144,222 \\
\hline
\end{tabular}

Notes: Dependent variable is log(employment) per firm in each year. Levels of significance: $10 \%^{*}, 5 \%^{* *}, 1 \%^{* * *}$. Standard errors are clustered at the firm level. FMW is measured on a $0-1$ scale in the regressions. The main effect of $F M W$ is absorbed by the firm fixed effects.

Table A12: Regression Estimates of Minimum Wage Effect on Profits (IHS $(\pi)$ ), Based on Estimated Mechanical Cost of Minimum Wage Increase, 2004-2005 and 2009-2010

\begin{tabular}{|l|c|}
\hline Variables & $(1)$ \\
\hline & Full sample \\
\hline Log relative minimum wage $(\log R M W)$ & $-13.065^{* * *}$ \\
& $(1.713)$ \\
\hline Log wage bill for minimum wage workers $\times$ log relative & $-0.269^{* * *}$ \\
minimum wage & $(0.093)$ \\
\hline Initial profits dummies & yes \\
\hline Initial profits $\times$ POST & yes \\
\hline Sector dummies and sector dummies $\times$ POST & yes \\
\hline Firm fixed effects & yes \\
\hline $\mathrm{R}^{2}$ & 0.732 \\
\hline $\mathrm{N}$ & 202,187 \\
\hline
\end{tabular}

Notes: Dependent variable is $I H S(\pi)$ per firm in each year. Specification includes firm fixed effects. Log relative minimum wage is defined as zero $(\log (1))$ for the pre-period and $\log (1.154)$ for the post-period, given the $15.4 \%$ increase in the minimum wage. The interaction measures the percent change in profits for a one-percent higher effect of the minimum wage increase of the wage bill (based on minimum wage workers in 2005). Levels of significance: $10 \%^{*}, 5 \%^{* *}, 1 \%{ }^{* * *}$. Standard errors are clustered at the firm level. $F M W$ is measured on a $0-1$ scale in the regressions. The main effect of $\log \left(W B M W_{i}\right)$ in equation (3) is fully absorbed by the firm fixed effects. 